\title{
Multiscale spatio-temporal variability of sedimentary deposits in the Var turbidite system (North-Western Mediterranean Sea)
}

\author{
V. Mas $^{a, b,{ }^{*}}$, T. Mulder ${ }^{b}$, B. Dennielou ${ }^{a}$, S. Schmidt ${ }^{b}$, A. Khripounoff ${ }^{c}$ and B. Savoye ${ }^{a}$
}

\author{
a Ifremer, Département des Géosciences Marines, BP70, F-29280, Plouzané, France \\ ${ }^{b}$ Université de Bordeaux I, UMR CNRS 5805 EPOC, Avenue des Facultés, F-33405 Talence, France \\ ${ }^{\mathrm{c}}$ Ifremer, Département des Ecosystèmes et Environnements Profonds, BP70, F-29280, Plouzané, \\ France
}

*Corresponding author : V. Mas, email address : virginiw.mas@gmail.com

\begin{abstract}
:
The Var turbidite system is a small sandy system located in the Ligurian Basin (Mediterranean Sea). It is active during present sea-level highstand and shows four types of sediment transfer processes: (1) low-density turbidity surges generated by small-scale failures (2) low-magnitude, high-frequency (yearly) hyperpycnal turbid plumes, (3) high-magnitude, less-frequent, hyperpycnal currents and (4) high-magnitude flows generated by large slope failures. These processes have different imprints on the morphology of the system. Inversely, the topography plays a role on the behaviour of these flows. The depositional and erosional architecture of the system has been investigated in detail on the basis of SAR imagery and a set of cores using an interface corer collected repetitively from a dense group of sites. The inner terraces located in the upper part of the turbidite system are generally depositional and thus provide a detailed record of recent sediment transfer processes. But the lower the elevation, the more terraces are affected by turbulent flow erosion. Downward, the channel-floor is a complex area where flows mainly by-pass but locally erode or deposit. The levee is dominantly depositional, but only records high-magnitude events, able to spill over. Low-magnitude, high-frequency events, such as yearly hyperpycnal currents are confined in the upper part of the system and thus have little control on system architecture. Moreover, they provide only thin deposits that can be misinterpreted in terms of involved process, and will probably be erased from the geological record. High-magnitude events have strong control on the system architecture as they erode the channel-floor and participate in the construction of the Var Sedimentary Ridge.
\end{abstract}

Keywords: Var; France; gravity processes; Mediterranean; turbidity current; hyperpycnal; flood 
40

Research on modern turbidite systems contributes to improve our knowledge of the sedimentary processes involved in sediment transfers from the continent to the deep seas (Piper and Normark, 2001). Understanding the spatial and temporal behavior of submarine sediment-laden gravity flows is of primary interest as it will directly control the architecture of deep-sea sedimentary systems and the distribution of sediment. Changes in slope gradient have a major influence on sediment deposition (Pickering et al., 1989), by controlling the non-uniformity of gravity flows or by confining them (Kneller \& Buckee, 2000). Local topographic changes generate local flow structures that affect the rates of transport, erosion and deposition, leading to diverse depositional signatures. Moreover, great attention should be paid to the relation between the present activity of processes and their preservation in the geological record. The alteration and preservation of sedimentary records, especially single-event layers, remains a key question for the understanding of deep-sea turbidite system construction and evolution. Investigations on marine sediments are limited because processes acting in a deep-sea turbidite system can be misinterpreted when based on sparse samples. To overcome this problem, repetitive and accurate coring with good spatial resolution is needed to understand the spatial and temporal evolution of sediment transfer processes from the continent to the deep sea.

The Var Canyon (Western Mediterranean Sea) records significant sediment transport during the present sea level highstand (Mulder et al., 1998). Earlier investigation provided evidences of sediment gravity flows related to floods of the Var River (Gennesseaux et al., 1971; Mulder et al., 2001a; Khripounoff et al., in press.), small-sized turbulent surges (Mulder et al., 1998) or massive slope failure such as the Nice airport slump and turbidity current in 1979 (Piper and Savoye, 1993; Mulder et al., 1997a; Dan et al., 2007). Furthermore, a terrace on the side of the Var Upper Submarine Valley offers a depositional site of very high sedimentation rate during the last century 
(Mulder et al., 2001b) which enables to understand how these events are recorded in the sedimentary series. Consequently, the Var Deep-Sea Turbidite System is a good place to study the occurrence and the behaviour of the different types of sediment transfer processes at different time and space scales. Using a new significant amount of data, this paper aims to investigate the distribution and evolution in time and space of the first meter of sediment lying below the seafloor. The role of the seabed morphology on the behaviour of turbulent flows will be addressed. A dense spatial set of recurrent piston cores recovered on several morphological features along the Var Canyon, valley and sedimentary ridge provides an opportunity to constrain the role of micro-topography on depositional processes.

\section{Regional settings}

\subsection{Geological setting}

The Var turbidite system is located in the Ligurian Sea off France (Fig. 1). The morphology of the continental slope results from the complex interactions between tectonic heritage, Messinian paleomorphology and sedimentary processes during the Quaternary (Mauffret et al., 1973). The continental shelf is very narrow (2-3 km) or even absent offshore the Var River mouth (Fig. 2). The steep continental slope has an average gradient of $13^{\circ}$ but values ranging up to $20^{\circ}-30^{\circ}$ are common (Mulder et al., 1996). Slopes greater than $30^{\circ}$ are found on the sides of the canyon (Mulder et al., 1996).

The Var turbidite system is connected to the Var and the Paillon rivers by two deeply incised canyons, the Var and the Paillon canyons (Fig. 2). The Var deep-sea fan began to form during the Messinian and developed during the Pliocene and Quaternary as the results of the progradation of the Var Delta (Savoye et al., 1993). 
- The Var Canyon extends from the river mouth to $1600 \mathrm{~m}$ water depth. The head of the canyon is sinuous and flat floored and the slope at the bottom decreases gradually from $11^{\circ}$ to $4^{\circ}$. Width gradually increases downwards from 300 and $1250 \mathrm{~m}$.

- At the confluence between the Var and the Paillon canyons (N43³0.9, E7²0), the Upper Valley extends $12 \mathrm{~km}$ south-eastward to water depths of $2000 \mathrm{~m}$. The slope at the bottom of the valley gradually decreases from $4^{\circ}$ to $2^{\circ}$.

- After an eastward bend (N43²6.8, E7²6.3) the valley widens and forms the $50 \mathrm{~km}$ long Middle Valley, down to water depths of $2500 \mathrm{~m}$. The end of the Middle Valley corresponds to a southeast bend, near a continuous line of salt diapirs, named the "Diapir Wall" (Savoye et al., 1993). The channel floor valley is divided into several minor channels, separated by large hillocks. The slope at the bottom of the Middle Valley decreases from $2^{\circ}$ to $0.3^{\circ}$. The Middle Valley is limited to the north by a small discontinuous levee, and to the south by a hypertrophied levee called the Var sedimentary ridge (Piper and Savoye, 1993). The cross-section of the Var Sedimentary Ridge is asymmetrical with a steep and narrow northern flank and a flat and wide southern flank. Its elevation from the seafloor decreases eastward from $400 \mathrm{~m}$ to less than $30 \mathrm{~m}$. In the eastern part of the Ridge, the boundary between the levee and the valley is gradual whereas upstream, steep walls separate the levee from the valley (Migeon et al., 2000).

- The Lower Valley extends over $100 \mathrm{~km}$ to the southeast. Its slope decreases from $0.3^{\circ}$ to $0.1^{\circ}$. It feeds the distal sandy lobe complex, at 2700 m water depth (Bonnel, 2005).

The floor of the Canyon to the Middle Valley is covered with gravel waves with a few metres in amplitude and 30 to $40 \mathrm{~m}$ in wavelengths (Malinverno et al., 1988). In the canyon, gravel waves are partially covered by a thin Quaternary mud layer (Klaucke et al., 2000). In the lower course of the valley, they are covered by Quaternary sediments but are exhumed at the base of large scours (Piper and Savoye, 1993). In the Var Sedimentary Ridge, a field of sediment waves partly covers the Ridge, 
115 from 2000 to 2600 m depth (Gennesseaux et al., 1985; Migeon et al., 2000). Levee deposits are

116 composed of sandy to muddy turbidites (Foucault et al., 1986; Migeon et al., 2000).

118 Terraces are found along the submarine canyon and valley. In the Var Canyon, the present terraces

119 lie at approximatively $50 \mathrm{~m}$ above the channel floor (Klaucke et al., 2000). The surface of these

120 terraces is irregular in the upper sinuous part of the canyon and become flat in the straight part of the

121 canyon. In the Upper Valley, on the left side, a terrace lies at $30 \mathrm{~m}$ above the channel floor. On the right side, the terrace lies between $30 \mathrm{~m}$ and $100 \mathrm{~m}$ above the channel floor.

Our study focuses on the upper part of the system, and includes the Var Canyon, Upper Valley, Middle Valley and the right-hand part of the Var Sedimentary Ridge.

\subsection{Oceanographic setting}

The major regional hydrodynamical feature in the Liguro-Provencal Basin is the Northern Current (Millot, 1991), a well-defined cyclonic circulation, approximatively 50 km-wide, mainly flowing anticlockwise along the coast (Millot, 1987). Its activity and structure change markedly seasonally. In summer, i.e. from June to November, the Northern Current is relatively wide and shallow and displays reduced mesoscale variability. In winter, i.e. from December to May, it becomes thicker and narrower and it tends to flow closer to the slope. Moreover, it commonly displays meanders with wavelengths ranging from tens to a hundred kilometres (Taupier-Letage and Millot, 1985). These meanders have phase speeds of 10-20 km/day (Millot, 1999). Moreover, in autumn, these meanders

137 fluctuate every 3-6 days, inducing a residual flow with a direction perpendicular to the coast 138 (Sammari et al., 1995). 
Mas et al., Marine Geology, corrected version

\subsection{Hydrographical and hydrological setting}

142 The Var River is a $120 \mathrm{~km}$ long mountainous river which drains an area of $2820 \mathrm{~km}^{2}$. Its main

143 tributaries are the Tinée, Vésubie and Estéron rivers. The river flows across geological formations

144 dominantly composed of marls and silts (Mulder et al., 1998). The mean annual water discharge, 145 calculated using data collected between 1985 to 2007 is $53 \mathrm{~m}^{3} / \mathrm{s}$ (Mulder et al., 1997b). The Var 146 River is subjected to flash floods, related to snow melting, in the spring and to storms in autumn 147 (Sage, 1976). During exceptional floods the water discharge can be up to a hundred times higher 148 than the annual mean. For example, in September 1994, the maximum discharge reached $3770 \mathrm{~m}^{3} / \mathrm{s}$.

149 The estimated sediment discharge at the mouth of the river ranges between 1.3 and $1.6 \times 10^{6} \mathrm{t} \mathrm{yr}^{-1} \mathrm{but}^{-}$ may be larger if suspended concentration related to floods occurring after a dry period is taken into account (Mulder et al., 1997b). Furthermore, these values do not include the bedload transport. During floods, suspended particle fluxes reach values ten times higher. For example, in September 1994, calculations show that the river flood transported $18 \times 10^{6}$ t of sediment to the sea, creating a hyperpycnal turbidity current (Mulder et al., 1997b).

\subsection{Previous work on gravity-flow processes and trigger mechanisms}

Gravity-flows are triggered by two main mechanism in the Var Turbidite System: mass-wasting, and river floods (Mulder et al., 1998 ; Migeon et al., 2006):

(1) Mass-wasting event mostly affect sediments of the upper part of continental slope. In the Var system are distinguished large slope failures from small ones. Large failures, potentially earthquake-

162 triggered, have a frequency of less than one event every 100 years (Mulder at al., 1998). These large-

163 scale sediment remobilization could be able to generate voluminous, high-magnitude turbidity flows 164 by transforming the mass-wasting through a transitional phase called ignition (Parker, 1982; Piper et al., 1992). The best-known example for such failure is the Nice airport failure (Gennesseaux et al., 
1980; Dan et al., 2007). This event generated an ignitive high-density current, which lasted more than 24 hours (Mulder et al. 1998). Small-scale mass-wasting are described as shallow failures, usually retrogressive and generally restricted to the uppermost layers of slope sediments, up to $10 \mathrm{~m}$ (Migeon et al. 2005). They are inferred to be triggered by the excess pore pressure created by the fast accumulation of sediment during floods (Mulder et al., 1998). They remobilize small volume of sediment compared to large-scale failures and thus, might probably generate small turbidity surges as

172 those observed by Gennesseaux et al. (1971). The estimated occurrence of such surges is one event 173 every 1 or 2 years (Mulder at al. 1998)

(2) River floods generating hyperpycnal turbidity currents are also a common process in the Var system (Khripounoff, 2009). Hyperpycnal flows are a particular sub-type of turbidity currents, generated by the plunging of a dense sediment plume during floods (Mulder et al., 2001a). This necessitates a critical concentration of $42 \mathrm{~kg} / \mathrm{m}^{3}$ in this climatic setting (Mulder et al., 2003). The corresponding threshold in discharge for the Var River is approximately $1250 \mathrm{~m}^{3} / \mathrm{s}$ (Mulder et al., 1997b). Using these parameters, statistical computation suggested that the Var River can generate a flood forming a hyperpycnal flow every 3 to 21 years (Mulder et al., 1998). This estimate could be reduced using the reconcentration processes such as convective sedimentation (Parsons et al., 2001).

182 Thus, hypopycnal (surface) plume with a sediment concentration as low as $1 \mathrm{~kg} / \mathrm{m}^{3}$ may form a 183 hyperpycnal flow.

3. Materials and methods

The bathymetric map is a compilation of multibeam EM300 (frequency of $30 \mathrm{kHz}$ ) data from ESS300/1 and GMO1 research cruises (2000 and 2001 respectively, R/V Le Suroît). The grid interval in the digital terrain model is $50 \mathrm{~m}$.

189 Side-scan sonar images were collected during the SAME cruise with the French S.A.R. (Système 190 Acoustique Remorqué). The S.A.R. side-scan antenna has a $200 \mathrm{kHz}$ frequency. The vehicle is 
191 towed at about 100-150 m above the seafloor at a speed of 2 knots. The survey covers a surface of

$1921300 \mathrm{~km}^{2}$ compiled into a mosaic. The pixel size is $7 \mathrm{~m}$.

193 Main studied cores come from interface corers. A multi-corer provided by INSU (Institut National

194 des Sciences de l'Univers) was used during the ENVAR1, 3, 4, 5 and 6 cruises and a push-corer 195 (called “Ronanberg”) was used during ENVAR2 cruise (fig. 2).

After splitting, cores were described visually, according to the grain size (mud, silt, sand, cobbles, etc.), structures (laminations, bioturbation), contacts and colour. 10-mm-thick slabs were sampled for radiography imaging with the Scopix system (Migeon et al., 1999). Grain size analyses were performed with a Coulter LS130 laser microgranulometer. Samples for grain size analysis were carefully collected every $2 \mathrm{~mm}$ in order to avoid mixing with adjacent sediment. Additional samples were taken in laminae and thin sequences. Mud samples were exposed to ultrasounds until complete suspension to avoid amalgamation (Mc Cave et al., 1995).

Chronology was determined using ${ }^{137} \mathrm{Cs}$ (30 years) and excess ${ }^{210} \mathrm{~Pb}\left(22.3\right.$ years). The ${ }^{210} \mathrm{~Pb}_{\mathrm{ex}}$ method gives an average accumulation rate for the past 100 years, while ${ }^{137} \mathrm{Cs}$ is applicable for the last 45 years, corresponding to its first appearance in the atmosphere due to anthropogenic activities. Radioisotope measurements were made using a semi-planar germanium detector (EGSP 2200-25-R, EURYSIS Measures) (Schmidt et al., 2007). Standards used for the calibration of the $\gamma$ detector were IAEA standards (RGU-1, RGTh-1). ${ }^{210} \mathrm{~Pb}$ in excess of equilibrium with ${ }^{226} \mathrm{Ra},{ }^{210} \mathrm{~Pb}_{\mathrm{ex}}$, was calculated 211 as the difference between measured ${ }^{210} \mathrm{~Pb}$ and ${ }^{226} \mathrm{Ra}$.

212 Sediment accumulation rate can be derived from ${ }^{210} \mathrm{~Pb}_{\mathrm{ex}}$, based on two assumptions: constant flux 213 and constant sediment accumulation rate (Robbins and Edgington, 1975; Schmidt et al.). Then, the

214 decrease of ${ }^{210} \mathrm{~Pb}_{\mathrm{ex}}$ activity with depth is described by the following relation:

$215 \quad\left[{ }^{210} \mathrm{P} b_{\mathrm{ex}}\right]_{z}=\left[{ }^{210} \mathrm{~Pb}_{0}\right]_{0} \exp \left(-z \frac{\lambda}{\mathrm{S}}\right)$ 
216 where $\left[{ }^{210} \mathrm{~Pb}_{\mathrm{ex}}\right]_{0, \mathrm{z}}$ is the activity of excess ${ }^{210} \mathrm{~Pb}$ at sediment -sea water interface (or the base of the mixed layer) and at the depth below the seafloor $\mathrm{z}, \lambda$ is the decay constant of the nuclide, and $\mathrm{S}$ is the sediment accumulation rate. This equation was not applicable to some cores presenting almost constant ${ }^{210} \mathrm{~Pb}_{\mathrm{ex}}$ activity with depth (i.e. rapid deposition or mixing), and/or presenting eroded 220 surfaces and thick turbiditic layers (leading to a variable sediment accumulation rate). Thus, for 221 irregular decrease of ${ }^{210} \mathrm{~Pb}_{\mathrm{ex}}$ activity with depth, we calculated minimum accumulation rates by 222 dividing the deepest cored intervals containing activity by the maximum possible age for ${ }^{210} \mathrm{~Pb}_{\mathrm{ex}}$ 223 ( 100 years) and ${ }^{137}$ Cs detections (46 years; (Jaeger et al., 1998). However, because cores are 224 relatively short $(<1 \mathrm{~m})$, the end ${ }^{210} \mathrm{~Pb}_{\mathrm{ex}}$ was not always reached and accumulation rates can be higher 225 than those calculated.

\section{Results}

\subsection{Sedimentary and morphological features}

In the Var Canyon, a terrace (A) is located on the left side of the straight part of the canyon (Fig. 2) at water depths ranging from $1400 \mathrm{~m}$ to $1640 \mathrm{~m}$. The terrace is $5 \mathrm{~km}$ long and $800 \mathrm{~m}$ wide, with an elevation of 20 to $30 \mathrm{~m}$ above the canyon floor and a mean slope of $6^{\circ}$. SAR images show numerous erosional bedforms such as furrows and scours (Fig. 3). These are roughly parallel to the canyon axis. Furrows are $100 \mathrm{~m}$ long on average but can be up to $600 \mathrm{~m}$ long. Some furrows converge to large scours, V-shaped pointed upstream. Scours have a sharp upper boundary and a flared and diffuse downslope termination. They are up to $1 \mathrm{~km}$ long, $600 \mathrm{~m}$ wide and up to $5 \mathrm{~m}$ deep. They cut across fine-grained sediments and exhume gravel waves underneath. $1900 \mathrm{~m}$ (Fig. 4). This terrace is elongated and roughly parallel to the channel axis. It is $3 \mathrm{~km}$ long 
and $700 \mathrm{~m}$ wide with an elevation of 10 to $40 \mathrm{~m}$ above the channel floor and a mean slope of $6^{\circ}$. On

242 SAR Imagery (Fig. 4), the surface appears to be slightly mounded. Furrows and scours are observed, 243 but are less abundant than in the Var canyon. Furrows are up to $200 \mathrm{~m}$ long. Scours, up to $50 \mathrm{~m}$ 244 wide, are V-shaped. Scours and furrows cover about $50 \%$ of the surface of the terrace.

245 On the right of the Upper Valley, a terrace (C) is observed at water depths ranging from 1780 to 2462000 m (Fig. 5). It can be divided into four smaller sub-terraces, with different elevation from the 247 channel axis. From north to south, sub-terrace C1 is oval shaped, $500 \mathrm{~m}$ long and $300 \mathrm{~m}$ wide with 248 an elevation of $100 \mathrm{~m}$ above the channel floor. Sub-terrace C2 is $1600 \mathrm{~m}$ long and $700 \mathrm{~m}$ wide, with 249 an elevation of $75 \mathrm{~m}$ above the channel floor. Sub-terrace C3 is a $900 \mathrm{~m}$ square, prolonged to the south-east by a $1300 \mathrm{~m}$ long and $200 \mathrm{~m}$ wide strip along the sidewall. Terrace elevation above the channel floor is $65 \mathrm{~m}$. Sub-terrace C4, southernmost and longest terrace in the Upper Valley, is 4800 $252 \mathrm{~m}$ long and $900 \mathrm{~m}$ wide. Its elevation above the channel floor is $50 \mathrm{~m}$ and decreases gradually to a 253 few metres towards the south. Its distal termination is found at the beginning of the Middle Valley, 254 below the base of the continental slope.

The terrace floors are generally flat and have a mean slope ranging between 4 and $1^{\circ}$. They have a mostly smooth surface with only few thin lineations (as shown by SAR imagery).

The Middle Valley begins at about 2000 m water depth and widens abruptly. The valley floor shows three shallow channels (Fig.2). A northern channel (up to $20 \mathrm{~m}$ deep and $700 \mathrm{~m}$ wide) runs to the north-east and follows the base of the continental slope. It is bounded to the south by a 6 to $20 \mathrm{~m}$ high levee. A southern channel (14 m deep and 2 km wide) runs along the Var Sedimentary Ridge. A central channel (80 m deep and $4 \mathrm{~km}$ wide) runs in the middle of the Valley. In the southern channel,

263 the acoustic backscatter on the SAR imagery (Fig. 6) indicates a heterogeneous distribution of sediment along the channel floor, with low-backscatter patterns corresponding to sediment patches. Abundant kilometre long scours with irregular shape deeply incise the channel floor and show ancient gravel waves. Gravels probably result from reworking of the Messinian erosional surface 
(Malinverno et al. 1988) and could not have been transported by recent sediment gravity flows

268 (Mulder et al. 1997a). The main flows directions have been inferred from the orientations of scours, 269 furrows and depositional patches. The orientation of bedforms varies from ENE to ESE., The gravels wave orientations, ESE, must indicate either remnant Pleistocene flow direction or could be shaped by Holocene flows (Klaucke et al, 2000). These orientations indicate a dominant easterly transport direction in agreement with the general channel pathway direction. Considering that each bedform 273 has probably been formed by a single flow, the variation in bedform directions indicates that flows do not follow a unique pathway and thus are not really confined in this part of the channel.

The Var Sedimentary Ridge is characterized by a smooth surface with kilometre-scale undulations interpreted as sediment waves (Migeon et al., 2000). The inner and steeper side of the ridge show numerous failure scars.

\subsection{Sedimentary facies and sequence description}

Nine sedimentary facies were identified using the sediment nature, grain size and sedimentary structures (Fig. 8).

Facies 1 (pebble layer) consists of a one cm thick layer of rounded pebbles, surrounded by clay. The basal contact is erosive. Size of pebbles ranges between $2 \mathrm{~cm}$ and $3 \mathrm{~cm}$. Pebbles are granite, schist and conglomerate. The muddy matrix seems to have been deposited by the fall-out process after the deposition of pebbles.

Facies 2 (massive or poorly graded sand) consists of one to a few centimetre-thick massive to poorly graded coarse-sand layers. Contacts are usually erosional at the base and sharp at the top. The median of the grain size curve ranges from 63 to $540 \mu \mathrm{m}$. Clay content never exceeds $10 \%$. The 
Mas et al., Marine Geology, corrected version

basal first centimetre of the bed sometimes shows a reverse grading and contains mud clasts. Main constituents are angular to sub-angular quartz, detrital carbonates, rounded grains of granite and siltstone. Micas and vegetal debris are rare.

Facies 3 (laminated graded sand) consists of centimetre to decimetre-thick, graded medium to coarse-sand beds. Contacts are sharp at the base and sharp to diffuse at the top. The median of the grain size curve varies from 63 to $430 \mu \mathrm{m}$. These beds are normally graded, but several grain size breaks (sharp coarsening-up and steady fining-up) occur. Numerous inframillimetric laminae are visible on radiographs. The main constituents are subangular quartz, detrital carbonates and micas.

Facies 4 (graded fine sand showing a variety of sedimentary structures) consists of beds of a few centimetre-thick graded fine sand. Basal and upper contacts are sharp to diffuse. The median of the grain size curve varies from 40 to $120 \mu \mathrm{m}$. Radiographs show several types of sedimentary structures including wavy parallel laminae or oblique discontinuous laminations (ripple cross laminations). The main constituents are subangular quartz and detrital carbonates, vegetal debris and micas.

Facies 5 a (graded to ungraded laminated clayey silt) is composed of a few to fifty-millimetre thick normally graded to ungraded silt to silty-clay layer. Contact at the base is sharp to gradational. When it is sharp, the base is overlaid by a thin layer (less than $2 \mathrm{~mm}$ ) of fine sand or silt lamina. Upper contact is gradational. The median of the grain size curve ranges from 8 to $40 \mu \mathrm{m}$. The normally graded silt-to-mud beds commonly display parallel and indistinct silty microlaminations (less than 1 mm thick). These laminations are clearly seen on X-Ray imagery. Bioturbation is rare.

Facies $5 b$ (homogeneous clayey silt) consists of millimetre thick to centimetre thick intervals of clay to muddy sediment. Basal and upper contacts are gradational. The median of the grain size curve 
ranges from 7 to $30 \mu \mathrm{m}$. Some intervals show fine silt lenses and crude planar laminae. Bioturbation can be abundant.

Facies 6 (homogeneous structureless silty clay) consists of millimetre thick intervals made of siltyclay. Basal and upper contacts are generally diffuse but can be sharp. The median of the grain size curve is less than $10 \mu \mathrm{m}$. The ratio between biogenic and terrigeneous content never exceeds 1/3. Biogenic compounds contain calcareous nannoplankton, scarce foraminifera, and scarce siliceous spicules. There are less than $40 \%$ of present species mixed with reworked Mesozoic species. Facies 6 is rare.

Facies 7 (inversely graded silt and fine sand) consists of millimetre to centimetre thick layers of clay to silt that coarsens upward to silt to fine sand. Contacts are generally sharp at the base and gradational or erosive at the top. The median of the grain size curve ranges from 7 to $130 \mu \mathrm{m}$. In the thickest layers, some thin discontinuous or wavy laminations can be observed on radiographs. The main constituents are subangular quartz and carbonates, vegetal debris and micas.

Facies 8 (blurred silty-clay) consists of a millimetre to centimetre thick layer of silty clay. Contacts of this layer are diffuse and gradual. The median of the grain size curve is around $20 \mu \mathrm{m}$. The sediment is poorly sorted. Scarce-parallel silt laminations and bioturbation are sometimes observed.

Facies 9 (bioturbated sediment) consists of centimetre to decimetre thick layers of sediment where sedimentological interpretation is impossible, due to excessive bioturbation. This facies contains grey to brown sandy mud. The median of the grain size curve ranges from 8 to $90 \mu \mathrm{m}$. Bioturbation

341 is made of bright sub-rounded patches enclosed in a darker matrix or blurred levels of unsorted and homogeneous sediments. 
343 The sedimentary facies are grouped into five sequences (Fig. 8). Note that "sequence" is used

344 throughout in the sense of an "event sequence". The relative abundance of sequences, summarized in

345 Table 1 for each studied area, is illustrated by the most representative core in Fig. 9.

347 Sequence I consists facies 2, i.e. poorly graded sand containing less than $10 \%$ of clay, with erosive to 348 sharp basal and upper contacts. The sand layer can be overlaid by a silty clay layer (facies 5) through 349 an intra-sequence sharp contact. The base of the sequence can show inverse grading and/or mud 350 clasts. This sequence occurs in three cores located on terrace B, sub-terrace C3 and on the crest of the Var Sedimentary Ridge (Fig. 9).

Sequence II consists from the base to the top of the superposition of facies 2 to 6 , i.e. massive or poorly graded sand (with a possible inverse grading at the base), laminated sand, graded sand (sometimes with sedimentary structures), silt and silty clay. The basal contact is erosive. The upper contact is sharp to gradational. This fining upward sequence is found in cores from the channel floor of the Middle Valley, and on sub-terrace C4.

Sequence III consists from the base to the top of the superposition of facies 5a, 5b and rarely 6, i.e. laminated clayey silt grading to homogeneous silty clay. This fining upward sequence is generally found on terrace C (Upper Valley) and on the crest of the Var Sedimentary Ridge.

Sequence IV is characterized by the superposition of a normally-graded facies superimposed on an

364 inversely graded facies. Two types of sub-sequences are distinguished:

365 - Sequence IVa consists from the base to the top of the superposition of facies 7 (inversely graded), facies 4 , facies 5 ( $5 a$ then $5 b$, or only $5 a$ ) and facies 6 . The contact between facies 7 and 4 is erosive or sharp. Sequence IVa occurs dominantly in the Middle valley floor, where sediments are coarser.

368 One sequence 4a has been observed in each core of sub-terraces C. 
- Sequence $I V b$ consists from the base to the top of the superposition of facies 7, facies 5 (5a and/or

5b) and facies 6 . Contact between facies 7 and facies 5 is sharp or gradual. Sequences IVb are mostly

371 found on cores from the levee and terraces C.

372

373 Sequence $V$ consists from the base to the top of the superposition of facies 8 , facies $5 \mathrm{~b}$ and/or facies

374 6. This sequence can be observed on each studied area, but is mostly found on cores from the sub375 terraces $\mathrm{C}$.

\subsection{Radioisotope measures and chronological framework}

${ }^{210} \mathrm{~Pb}_{\mathrm{ex}}$ activity measured in sediments ranges from 100 to $450 \mathrm{mBq} / \mathrm{g}$ at the surface (Fig. 10).

On the Var Sedimentary Ridge, values of ${ }^{210} \mathrm{~Pb}_{\mathrm{ex}}$ decrease exponentially with depth. Calculated

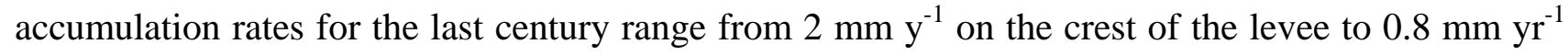
on the external flank of the levee. On the channel floor of the Middle Valley, the estimated accumulation rates range between 0.9 and more than $1.8 \mathrm{~mm} \mathrm{yr}^{-1}$. In the Var Canyon, on the terrace $\mathrm{A},{ }^{210} \mathrm{~Pb}_{\mathrm{ex}}$ and ${ }^{137} \mathrm{Cs}$ were only detected in the upper $10-20 \mathrm{~cm}$ and stop on erosional contacts. The estimated sedimentation rates for the last century range between 2.5 and $4 \mathrm{~mm} \mathrm{yr}^{-1}$. On terrace $\mathrm{B}$, the

386 sedimentation rate is estimated at $0.5 \mathrm{~mm} \mathrm{yr}^{-1}$. On sub-terrace C3, the activity of ${ }^{137} \mathrm{Cs}$ is still 387 detected at the bottom of the core, at a depth of $80 \mathrm{~cm}$. Thus, accumulation rate exceeds $16 \mathrm{~mm} \mathrm{yr}^{-1}$. 388 On sub-terrace C4, estimated accumulation rate reaches $14 \mathrm{~mm} \mathrm{yr}^{-1}$. 
Mas et al., Marine Geology, corrected version

\subsection{Interpretation of sequences in terms of gravity flow processes and possible trigger} mechanisms

Facies 6 and 5b (structureless silty clay and clay) are interpreted as hemipelagites. They are mostly composed of terrigeneous particles, probably supplied by the Var River. The biogenic fraction never exceeds 30\%, even at cored areas located far from the Var River mouth.

In sequence I, the presence of a sharp to erosive base suggests an energetic process for the deposition of this sequence. The massive sand or gravel layer, without any sedimentary structures can result from several types of flows : laminar grain flows (Middleton and Hampton, 1973), debris flows (Nardin et al., 1979), sustained turbidity currents (Kneller, 1995) or concentrated flows (Mulder and Alexander, 2001). The presence of floating mud clasts and/or a thin inverse grading at the base suggests erosion and particle support by upward dispersive pressure. These characteristics, associated with sharp upper and basal contacts and no grading (or crude inverse grading at the base of the sequence) suggest a deposit resulting from a laminar flow (Lowe, 1982). This deposit is encountered in concentrated density flows, where the flow is composed of a thick laminar basal part, despite that a turbulent upper part might exist (Mulder and Alexander, 2001). Concentrated flows are generally described as the transformation of a mass-wasting but Piper and Normark (2009) argued that these flows could also be commonly initiated onto steep slopes by hyperconcentrated bedload in hyperpycnal flows. Direct freshwater flow of hyperconcentrated bedload, with inertial effects predominating, was proposed by Prior and Bornhold (1989) for the Bear Creek fan delta in British Columbia. Similar interpretation have been suggested by Mulder et al. (2009) for the marine hyperconcentrated flow deposits related to the Malpasset dam failure in southern France. However, in the Var turbidite system, sequences I observed in cores have been deposited through the last century. At this time-scale, there is no evidence of catastrophic floods able to generate a 
In sequence II, the presence of a sharp or erosive basal contact associated with normal grading is a common criterion to distinguish waning flow (Kneller, 1995). In this case, sequence II can be interpreted as the classical turbidite deposition, i.e. the Bouma sequence (Bouma, 1962), where the massive or poorly-graded coarse sand at the base of the sequence (Ta unit) corresponds to the freezing of a basal concentrated flow under laminar regime (Mulder and Alexander, 2001). The laminar regime can explain the thin inverse grading and the incorporation of mud clasts sometimes observed at the base of the sequence (Lowe, 1982). The superimposed facies (3 to 6), normally graded and showing sedimentary structures suggest that the basal laminar flow is superimposed by an upper turbulent flow. This kind of deposit is generally related to a slump-initiated high-density turbidity flow (Mulder and Alexander, 2001) but several arguments can be given to link them to river-flood induced hyperpycnal flows. However, sequence II could result from a high-magnitude hyperpycnal current, generated during floods of exceptionally high magnitude where the river discharge and the current velocity reached during the flood peak is high enough to erode the basal coarsening-unit (Mulder et al., 2001a). However, sequence II could also result from a high-density turbidity flows initiated by a hyperconcentrated bedload in hyperpycnal flows (Piper and Normarck, 2009). But, as mentioned for sequence I, there is no evidence of such catastrophic flood event through the last century and thus, sequence II is interpreted as the deposit of a slump-generated highdensity turbidity current.

In sequence III, the presence of a sharp to erosive contact at the base, associated with a normal grading from sandy-silt to silty-mud and with laminations suggests a deposition by a turbulent waning flow (Kneller, 1995). Thus, sequence III can correspond to Td-e units of the Bouma sequence (Bouma, 1962). The lack of bedforms such as cross laminations may be indicative of short 
duration events (Mulder and Alexander, 2001). In the Var turbidite system, fine-grained normally

graded deposits are known to have two kinds of origin (Mulder et al., 1998). They can result from

445 turbulent surges triggered by failures and from hyperpycnal flows generated by flash floods

446 (Gennesseaux et al., 1971; Mulder et al., 2001a), where insignificant deposition occurs during the waxing phase, because of the rapid increase in initial velocities (Mulder and Alexander, 2001). Thus, sediments are deposited only during the waning phase and form the classical Bouma facies (Mulder et al., 2001a). Without complementary information, the flow initiation cannot be directly inferred 450 from the deposition of sequence III.

Sequence IV is characterized by a sharp basal contact, a coarsening-up unit, a gradual to erosive intra-sequence contact and a normal grading unit. The thin laminations observed in the basal coarsening-upward unit cannot be induced by a laminar regime and indicates that traction acts simultaneously to progressive particle settling (Mulder and Alexander, 2001).This characteristic indicates a turbulent regime and suggests a deposition from a depletive waxing flow (Kneller, 1995). The upper layer, normally graded and associated with sedimentary structures such as laminations suggests a deposition resulting from a turbulent waning flow (Kneller, 1995). The entire sequence is thus interpreted as a complete hyperpycnite (Mulder et al., 2001a). When the intra-sequence contact is sharp to erosive (sequence IVa) it indicates that the velocity reached during the flood peak is high enough to prevent deposition or to erode (Mulder et al., 2001a). Furthermore, in sequence IVa, the upper normally-graded unit is composed of a graded sand layer showing sedimentary structures such as ripple-cross laminations passing-up to laminated silt and to fine sediment (Tc-e units of the Bouma sequence). The development of such sedimentary structure indicates a relatively longduration flow (Mulder and Alexander, 2001). These characteristics indicate that sequence IVa is deposited by a hyperpycnal flow generated by a high-magnitude flood (Mulder et al., 2001a). When the intra-sequence contact is gradual to sharp (sequence IVb) it indicates that the velocity reached during the flood peak is not capable to erode. Moreover, sequence IVb is fine and thin, and thus, is 
469 inferred to be deposited by a hyperpycnal current generated by a low-magnitude flood (Mulder et al., 470 2001a)

472 Sequence $\mathrm{V}$ is composed by a layer of mainly silty sediment with gradational contacts. It differs 473 from the surrounding hemipelagites by a mostly greyish color and higher fraction in silt and fine 474 sand. The poorly sorted grain size and the lack of sedimentary structure may indicate a dominant 475 fall-out deposition that could be related to (i) deposition by the tail of small turbidity flow formed in the adjacent canyon, or (ii) the fall-out of a hypopycnal plume formed at the river mouth during low magnitude floods. For the latter, previous works have shown that plume deposits are generally found on the uppermost continental slope (Klaucke et al., 2000). In the Ligurian Sea, surface plumes can be deflected by surface current, and dispersed mainly eastward along the coast (Sage, 1976). However, meandering of the Northern Current, and related residual flow perpendicular to the coast (Sammari et al., 1995) can disperse hypopycnal plumes and thus, suspended sediment may be carried away and be deposited by fall-out processes far from the coast. Sequence V could also result of a postdeposition alteration of the finest sediments, such as hemipelagites or Td-e terms of turbidites, by bioturbation or resuspension by bottom currents (Wheatcroft and Drake, 2003).

\subsection{Morphological controls on sedimentary processes}

\subsubsection{Control of morphology at the scale of the Var system}

The distribution of acoustic facies observed using SAR imagery and the distribution of dominant sedimentological sequences observed in cores allow establishing a schematic map of the depositional and erosional patterns (Fig. 11). Erosional pattern is estimated by the relative abundance of erosional

493 bedforms in SAR imagery and of erosional contacts in sedimentological sequences. The depositional 
pattern is a combination of the mean sedimentation rate and the average number of sequences deposited and preserved at the centennial scale. The overall distribution of these patterns is controlled by the turbidite system-scale morphological features, i.e. (1) the channel floor, (2) the levee and (3) the inner terraces.

(1) In the Middle Valley channel floor, erosive and/or by-pass processes are dominant. Sedimentation is localized on isolated patches (Fig. 6) and mainly corresponds to coarse sandy sequences (type II and IVa) of a few to ten centimetres thick (see VB-08 in Fig. 9). No correlation between cores can be established, even between those distant of less than 100 metres. There is no evidence that the flows follow preferentially one of the three channels inside the Valley.

(2) The western part of the Var Sedimentary Ridge is a depositional area. This part of the levee is elevated around 280 metres and its surface is smooth (Fig. 7). The thin and fine-grained deposits, almost corresponding to sequences III, IVb and V, are interpreted as typical spill-over deposits corresponding to the deposition of the upper part of slump-induced turbidity flows or hyperpycnal currents (Migeon et al., 2000) similar to those found on other turbidite systems levees (Hesse and Chough, 1980; Piper and Deptuck, 1997). Due the elevation of the levee, we suggest that only highmagnitude flows are able to spill over and depose sedimentary sequences. However, Mulder at al. (1998) suggested that slump-generated turbidity flows hardly spill over this part of the Var Sedimentary Ridge, because they are generally not thick enough to reach the top of the levee. Furthermore, the occurrence of high-magnitude slump-generated turbidity flows is weak, with one event every 100 to 1000 years (Mulder et al., 1998). Thus, at the scale of the last century, we suggest that most of the deposits found in this part of the levee, including sequence III could result from high-magnitude hyperpycnal currents. There are no erosional structures in sediments deposited through the last century. This indicates that during this period this part of the Var Sedimentary Ridge underwent accumulation only. With an average number of 6 sequences deposited through the last century and an accumulation rate of 1.3 to $2 \mathrm{~mm} \mathrm{yr}^{-1}$ (Table 1), spillover deposits occurred at an 
average rate of 1 event every 15 year. The morphology of the Var Sedimentary Ridge shows numerous slide scars on the inner flank and on the crest, indicative of mass wasting. Moreover, a deposit which could result from the deposition by a concentrated density flow (sequence I) is also found in one core sampled on the crest (core VC-04, Fig. 9). However, this part of the levee is too high to record the basal laminar part of a concentrated density flow coming from the channel floor (Migeon, 2000). Consequently, this sequence is interpreted as the longitudinal evolution of a mass wasting (Mulder and Cochonat, 1996) triggered on the levee crest. This kind of process can lead to a significant erosion of the levee. However, in our sediment cores there is only one evidence of deposits related to mass wasting. It suggests that this process has a low frequency at centennial scale and confirms that at this time-scale, depositional processes dominate on the Var Sedimentary Ridge.

(3) The dominant sedimentary processes on the inner terraces depend on the elevation above the

531 canyon and channel floor. Terrace C is mainly a depositional area. Its surface, lying between 50 and 532100 metres above the channel floor, is characterized by a smooth surface with few erosional scars. 533 Sediments are mostly composed of numerous silt to fine sand sequences (type III, IVb and V, see 534 Table 1). All the deposits indicate an occurrence of 1 event every 1.5 years with accumulation rates 535 of $16 \mathrm{~mm} \mathrm{yr}^{-1}$ over the last 50 years (Table 1). Terrace A and B, 10 to $40 \mathrm{~m}$ above the channel floor, 536 show numerous scours indicative of significant erosion and sediment reworking. The depth of the 537 scours indicates that erosion can reach up to 5 metres. Underlying Pleistocene gravel waves are 538 visible here (Klaucke et al., 2000). Sediments are composed of coarse silt sequences that commonly 539 show erosional bases. Seven sequences are meanly deposited in terrace A through the last century, 540 and three sequences in terrace B. It represents an occurrence of 1 event recorded and preserved every 54114 to 33 year and an accumulation rates of 0.4 to $4 \mathrm{~mm} \mathrm{yr}^{-1}$ over the last 100 years (Table 1 ). These 542 relatively low sediment accumulation rates and the erosional features on the sea floor and at the base 543 of sequences show that depositional processes are counterbalanced in these areas by erosional 544 processes. Nevertheless, at the scale of the last century, the inner terraces appear to be more 545 accumulative than the levee (Table 1). 
Mas et al., Marine Geology, corrected version

Recent sedimentary processes on terrace C (Upper Valley) are dominantly depositional. The spatial

continuity of sedimentary sequences allows a core to core correlation along the terrace, and thus to discuss the influence of the local morphology on the facies at the scale of a few metres to several kilometres (Fig. 12). Core sites, in sub-terraces C2, C3 and C4 (see Fig.5 for core location) are flatfloored, with a mean slope of $1^{\circ}$ to $1.8^{\circ}$, elevation above the canyon floor range from $75 \mathrm{~m}$ (upstream) to $40 \mathrm{~m}$ (downstream).

Major sedimentary sequences of a few to ten centimetres thick are recorded along the terrace. On the other hand, fine-grained sequences of few millimetres to centimetres thick (type III, IVb and V) are not recorded all over the terrace. In this proximal part of the turbidity system, these sequences are probably related to low-concentration, short-duration and small-sized flows (Stow and Bowen, 1980), which probably do not fill the whole channel. The lack of continuity of the thin sequences 559 along the terrace and the discrepancies of their thickness may be related to the variability in the 560 overspill of turbulent billows on the upper part of the flow. However, the absence of some thin 561 sequences may also result from obliteration, by bioturbation or bottom current resuspension 562 (Wheatcroft and Drake, 2003).

563 Thin sequences of type III, IVb and V are less frequent in sub-terrace C4 (core IENV2-16, see Fig. 564 12), where the elevation on terrace $C$ is the lowest. From this location, the slope of the canyon floor 565 decreases rapidly and the canyon widens. The very likely resulting decrease in velocity of flows may 566 enhance deposition of sediment upstream of the core site. On the other hand, because of the lower 567 elevation of sub-terrace C4 compared to others sub-terraces C1 C2 and C3, deposits could also been 568 more easily eroded by the basal part of the flows.

569 The identification of sedimentary processes is determined from the composition, grain size and 570 sedimentary structures of the deposits (Pye, 1994). However, based on cores correlation, the 571 identification of given sequences at different locations outline that a given flow can produce different 
signatures (patterns) in sedimentological archives. For example, the five sequences highlighted in the

573 grey frame on Figure 12 are clearly interpreted in one core as low-magnitude hyperpycnites 574 (sequence IVb), based on the presence of the coarsening-up unit at their base (Mulder et al., 2001a).

575 In others cores, the coarsening-up unit is not present and these deposits might be interpreted as a surge-like turbidites (sequence III), or as fall-out deposition by turbidity flow tails (sequence V). The absence of the coarsening-up unit shows that the local morphology including a steepening slope, 578 canyon narrowing or morphological obstacles, even at a metric scale, modify the flow dynamics 579 (Kneller, 1995). However, using our dataset, no trend in the deposition of the coarsening-up unit can be determined. Furthermore, there is no preferential site for recording of an entire hyperpycnal sequence. This means that the lack of this unit cannot be related to change in seafloor morphology influencing flow hydrodynamics. It suggests that (i) terrace surface floor is regularly re-shaped by the successive flows or that (ii) the different sedimentological patterns encountered at this scale for a single event are the result of the internal variability of the flow. preservation in the geological archive

Our study suggests that gravity-flows should be grouped in two main categories as a function of their magnitude and subsequent impact on the built-up and evolution of the Var turbidite system.

High-magnitude flows, which mobilize large amount of sediment with several grain-size populations through long distance, can be triggered by slope failures and by floods. Indeed, coarse inverse- then normally-graded sequences (type IVa) on the terraces and on the channel floor of the Middle Valley are inferred to be deposited by hyperpycnal currents and thus triggered by floods. Sequences I deposited in terraces B and C3 (IENV2-14 and IENV2-15 in Fig. 9) through the last century are interpreted as concentrated flows deposits and have been inferred to be slump-induced (see section 5.1). In terrace $\mathrm{C}$, the correlation between cores indicates that sequence I found in IENV2-15 is related to a sequence II in IENV2-16 (Fig.12). This suggests that between the two areas the 
concentrated flow has transformed into a high-density turbidity current. This transformation can be related to the decrease of slope, at the continental slope-rise transition below the terrace C4 (Fig. 2) and to a subsequent hydraulic jump undergone by the flow. High-magnitude flows have a great impact on the morphology of the turbidite system. In terms of erosion, in the canyon and in the Upper Valley, they probably contribute to form the erosionnal features such as giant scours observed on the channel floor (Klaucke et al., 2000) and the low-elevated terraces A and B (Fig. 3 and 4). On the channel floor of the Middle Valley, the presence of a complex pattern of erosional and depositional bedforms observed on the SAR imagery (Fig. 6), and the occurrence of few thick and coarse sequences (II and IVa) suggest that high magnitude flows have travelled in the Middle Valley and followed a complex pattern of channels and a low-elevation ridges (Piper and Savoye, 1003). In terms of deposition, the presence of sequences I, II and IVa in the terrace C, suggests that high magnitude flows can deposit significant amount of sediment at $70 \mathrm{~m}$ above the upper valley floor. The presence of some thin deposits (sequence III and IVb) deposited throughout the last century on the Var Sedimentary Ridge shows that the uppermost part of these high-magnitude flows can spill over the levee at an elevation of up to $300 \mathrm{~m}$ above the channel floor as, mentioned by Migeon et al (2006). High magnitude events also likely feed the terminal lobes (Unterseh, 1999; Bonnel, 2005).

Low-magnitude flows can be also triggered by slope failures and by floods. The type of trigger mechanism is hard to recognize from the sedimentary facies and sequences (see section 5.2.2). However, low-magnitude flows are expected to be dominantly low-magnitude hyperpycnal currents related to yearly floods as those reported by Khripounoff et al. (2009) or to be low-density turbulent surge (Ravenne and Beghin, 1983) related to shallow retrogressive small failures (Mulder et al., 1998). Since these flows are carrying small amount of material and have a short duration, they are mainly depositional and have a limited longitudinal and lateral extent (Mulder and Alexander, 2001). In that sense, they are most probably confined in the upper part of the turbidite system. On terrace C, where the recent turbiditic activity is the best recorded we have shown that sedimentary deposits during the last 50 years are corresponding dominantly (60-85\% of deposits and $90 \%$ of sequences) to 
624 thin (few millimetres to centimetres thick) fine-grained sequences (III, IVa and V). They poorly

625 impact the morphology of the system because (i) they are spatially limited to the canyon and the

626 Upper Valley and adjacent terraces, and because (ii) their thin deposits are easily eroded and

627 reworked by larger gravity flows. Nevertheless, they probably subsequently erode the low-elevated

628 terraces A and B, as suggested by the poor occurrence of sequences deposited and preserved here at

629 the scale of the last century (Table 1).

630 In the geological archive, it is very likely that the low magnitude events will be badly preserved

631 because they occur on terraces within the canyon and the valley and will probably be eroded and 632 reworded by the few high-magnitude flows. On the other hand, deposits from high-magnitude flows

633 will very likely be preserved because they are exported on the most remote area of the sytem, i-e the 634 top and the external flank of the sedimentary ridge and the terminal lobes. This mean that in fossil 635 systems turbidite facies are most likely representative of the biggest "events" with a return period of 636 several decades (e.g. return period of 16 year on the Var Sedimentary Ridge), while the sedimentary record of seasonal activity of the river or yearly slope failures in the canyon will be eventually erased 638 and badly preserved in the geological archive.

6. Conclusions

This new study presents data at various scales of both time and space. These data allow establishing a map of the relative importance of deposition and erosion over the whole turbidite system and highlight the complex interactions between morphology and sedimentary processes. The study improves the understanding of time-scale preservation of deposits. The following conclusions may be emphasized:

- Although the channel-floor is a dominantly by-pass area, localized and episodic sedimentation occurs, with one deposit every 25 years. 
- The dominant facies of inner terraces depends on their elevation above the canyon or channel floor. On low-elevation terraces, erosional processes counterbalance depositional processes. All deposits show erosional bases. Only a few deposits on high-elevation terraces show erosional bases and they record most of the recent processes (one deposit every 1-1.5 years). structures. Consequently, a single low-magnitude event has different sedimentological signatures

Six sequences deposited in the Var Turbiditic System have been observed and linked to two main categories of flows, related to their frequency and magnitude:

- Low-frequency, high-magnitude flows among which (i) concentrated flows and (ii) highdensity turbidity currents, generated by large slope failures potentially earthquakes-induced (Migeon et al., 2006) ; (iii) high-magnitude hyperpycnal currents, generated by Var River floods with a discharge tens time higher than the annual flood discharge.

- High-frequency, low-magnitude flow among which (iv) low-density turbidity surges related to shallow failures in sediment accumulated on the narrow continental shelf and (v) lowmagnitude hyperpycnal currents, probably generated by convective instability in hypopycnal plumes (Parsons et al., 2001); (vi) hypopycnal plumes or dilute tails of turbidity flows which convey, by suspension, turbid clouds of sediments through large areas and depose them by the fall-out process.

The magnitude of a flow controls its impact on the construction of the system and its preservation through geological archive. High-magnitude flows generate significant changes in the morphology of the turbidite system, because they are responsible for strong erosion in the canyon and in the valley and provide thick accumulation on the inner terraces and locally on the channel floor, and most of the fine-grained turbidites on the Var Sedimentary Ridge. Low-magnitude flows constitute the main part of the daily sediment flux. These events are not powerful enough to carry their sediment load into the deep sea, and remain confined in the upper part of the turbidite system (Canyon and Upper Valley). These short-duration, low-concentration events deposit thin beds with rare sedimentary which can lead to misinterpretation of the depositional process. As core correlation has shown, and 
as suggested by Mulder et al. (2001a), it appears that in the case of the Var River, most of fine-

grained turbidites are, in fact, base cut-out hyperpycnal sequences. Therefore, over the last fifty years, the Var turbidite system has recorded more hyperpycnal currents than theoretical frequency calculated by Mulder et al. (1998). The threshold of sediment concentration in a river plume necessary to generate hyperpycnal flow (Mulder et al., 2001b) must be re-evaluated as suggested by Parsons et al. (2001) to include convective sedimentation or other reconcentration processes.

Only voluminous deposits from high-magnitude flows are preserved on the geological time scale, by deposing coarse and thick sequences in the channel that could be preserved from erosion, and mostly by deposing sediments on the levee, which is barely submitted to erosion. Low-magnitude flows produce thin, fine-grained and discontinuous deposits, even at a metric scale, located inside the valley of the system. Thus, they are easily eroded by high-magnitude flows and hardly preserved in the deposits. This outlines the gap between the sedimentary processes acting in a turbidite system and their record in the sedimentary archive at a geological time scale.

Acknowledgments: The authors are grateful to J. Saint-Paul, G. Floch, M. Rovere for their assistance during data processing. We thank the Captain and crews of the R/V Le Suroît and Thetys 2 and IFREMER staff for their helpful assistance during the cruises. Sidonie Revillon, Julien Bourget, Gwénaël Jouet and Roland Mas are warmly thanked for improving a preliminary draft of this article. David J. W. Piper and the anonymous reviewers are warmly thanked for their valuable comments on the manuscript. This research was supported by the FP6 European project HERMES (Hotspot Ecosystem Research on the Margins of European Seas (Contract No. GOCE-CT-2005-511234-1).

Bonnel, C., 2005. Mise en place des lobes distaux dans les systèmes turbiditiques actuels: Analyse comparée des systèmes du Zaïre, Var et Rhône. Thèse de doctorat / université Bordeaux 1: (314 pp).

Bouma, A.H., 1962. Sedimentology of some flysch deposits: a graphic approach to facies interpretation. Elsevier, Amsterdam, 168 pp.

Dan, G., Sultan, N., Savoye, B., 2007. The 1979 Nice harbour catastrophe revisited: Trigger mechanism inferred from geotechnical measurements and numerical modelling. Marine Geology, 245(1-4): 40-64. 
Foucault, A., Baltzer, F., Glaçon, G., Lellouche, D., 1986. Turbidites et hémipélagites sur la pente sud de la ride du Var (mer Ligure, Méditerranée occidentale). Bulletin de la Société Géologique de France, 2(4): 675-679.

Gennesseaux, M., Foucault, A., Clerc-renaud, T., 1985. Les rides migrantes de l'éventail sous-marin du Var (Méditerranée nord-occidentale), Commission Internationale pour l'Exploration Scientifique de la Mer Mediterranée - Rapports et ProcèsVerbaux des réunions de Monaco, pp. 205-206.

Gennesseaux, M., Guibout, P., Lacombe, H., 1971. Enregistrement de courants de turbidité dans la vallée sous-marine du Var (Alpes-Maritimes). Comptes Rendus de l'Académie des Sciences de Paris, 273: 2456-2459.

Gennesseaux, M., Mauffret, A., Pautot, G., 1980. Les glissements sous-marins de la pente continentale niçoise et la rupture de câbles en mer Ligure (Méditerrannée occidentale), Comptes Rendus de l'Académie des Sciences de Paris Série D, pp. 959-962.

Hesse, R., Chough, S.K., 1980. The Northwestern Atlantic Mid-Ocean Channel of the Labrador Sea: II, depositional of parallel-laminated levee-muds from the viscous sublayer of low density turbidity currents. Sedimentology, 27: 697-711.

Jaeger, J.M., Nittrouer, C.A., Scott, N.D., Milliman, J.D., 1998. Sediment accumulation along a glacially impacted mountainous coastline: north-east Gulf of Alaska. Basin Research, 10(1): 155-173.

Khripounoff, A., Vangriesheim, A., Crassous, P., Etoubleau, J., 2009. High frequency of sediment gravity flow events in the Var submarine canyon (Mediterranean Sea). Marine Geology, 263(1-4): 1-6.

Klaucke, I., Savoye, B., Cochonat, P., 2000. Patterns and processes of sediment dispersal on the continental slope off Nice, SE France. Marine Geology, 162(2-4): 405-422.

Kneller, B., 1995. Beyond the turbidite paradigm: physical models for deposition of turbidites and their implications for reservoir prediction. Geological Society, London, Special Publication, 94(1): 31-49.

Kneller, B., Buckee, C., 2000. The structure and fluid mechanics of turbidity currents: a review of some recent studies and their geological implications. Sedimentology, 47(1): 62-94.

Lowe, D.R., 1982. Sediment gravity flows; II, Depositional models with special reference to the deposits of high-density turbidity currents. Journal of Sedimentary Research, 52(1): 279-297.

Malinverno, A., Ryan, B.F., Auffret, G., Pautot, G., 1988. Sonar images of the path of recent failure events on the continental margin off Nice, France. Geological Society of America Special Paper, 229: 59-75.

Mauffret, A., Fail, J.P., Montadert, L., Sancho, J., Winnock, E., 1973. Northwestern Mediterranean Sedimentary Basin from Seismic Reflection Profile. AAPG Bulletin, 57(11): 2245-2262.

Mc Cave, I.N., Manighetti, B., Robinson, S.G., 1995. Sortable silt and fine sediment size/composition slicing: Parameters for paleocurrent speed and paleoceanography. Paleoceanography, 10(3): 593-610.

Migeon, S., 2000. Dune géantes et levées sédimentaires en domaine profond: Approches morphologique, sismique et sédimentologique. Thèse de doctorat / université de Nice.

Migeon S, Garziglia S, Sage F, Sardou O (2005) Submarine landslides in the Ligurian basin: impact of sediment supply, earthquakes and salt tectonic. In: Abstract Volume of the Association of the French Sedimentologists Meeting, Presqu'île de Giens.

Migeon, S., Mulder, T., Savoye, B., Sage, F., 2006. The Var turbidite system (Ligurian Sea, northwestern Mediterranean)—morphology, sediment supply, construction of turbidite levee and sediment waves: implications for hydrocarbon reservoirs. Geo-Marine Letters, 26(6): 361-371.

Migeon, S., Savoye, B., Faugères, J.C., 2000. Quaternary development of migrating sediment waves in the Var deep-sea fan: distribution, growth pattern, and implication for levee evolution. Sedimentary Geology, 133(3-4): 265-293. 
Migeon, S., Weber, O., Faugères, J.C., Saint-Paul, J., 1999. SCOPIX: A new X-ray imaging system for core analysis. Geo-Marine Letters, 18(3): 251-255.

Millot, C., 1987. Circulation in the Western Mediteranean. Oceanologica Acta, 10(2): 143-149.

Millot, C., 1991. Mesoscale and seasonal variabilities of the circulation in the western Mediterranean. Dynamics of Atmospheres and Oceans, 15(3-5): 179-214.

Millot, C., 1999. Circulation in the Western Mediterranean Sea. Journal of Marine Systems, 20(1-4): 423-442.

Mulder, T., Alexander, J., 2001. The physical character of subaqueous sedimentary density flows and their deposits. Sedimentology, 48: 269-299.

Mulder, T., Cochonat, P., 1996. Classification offshore mass movements. Journal of Sedimentary Research, 66: 43-57.

Mulder, T., Migeon, S., Savoye, B., Faugères, J.C., 2001a. Inversely graded turbidite sequences in the deep Mediterranean: A record of deposits from flood-generated turbidity currents? GeoMarine Letters, 21(2): 86-93.

Mulder, T., Migeon, S., Savoye, B., Jouanneau, J.M., 2001b. Twentieth century floods recorded in the deep Mediterranean sediments. Geology, 29(11): 1011-1014.

Mulder, T., Savoye, B., Piper, D.J.W., Syvitski, J.P.M., 1998. The Var submarine sedimentary system: understanding Holocene sediment delivery processes and their importance to the geological record. Stoker, M.S., Evans, D; \& Cramp, A. (eds) Geological Processes on Continental Margin: Sedimentation, Mass-wasting and stability. Geological Society, London, Special Publication (129): 145-166.

Mulder, T., Savoye, B., Syvitski, J.-P.-M., 1997a. Numerical modelling of a mid-sized gravity flow: The 1979 Nice turbidity current (dynamics, processes, sediment budget and seafloor impact). Sedimentology, 44(2): 305-326.

Mulder, T., Savoye, B., Syvitski, J.P.M., Parize, O., 1997b. Des courants de turbidité hyperpycnaux dans la tête du canyon du Var? Données hydrologiques et observations de terrain (Hyperpycnal turbidity currents at the head of the Var Canyon ? Hydrological data and geological observations). Oceanologica Acta, 20(4): 607-626.

Mulder, T., Syvitski, J.P.M., Migeon, S., Faugères, J.C., Savoye, B., 2003. Marine hyperpycnal flows: Initiation, behavior and related deposits. A review. Marine and Petroleum Geology, 20(6-8): 861-882.

Mulder, T., Tisot, J.P., Cochonat, P., Bourillet, J.F., 1996. Regional assessment of mass failure events in the Baie des Anges, Mediterranean Sea. International Journal of Rock Mechanics and Mining Sciences and Geomechanics Abstracts, 33: 5A-5A.

Mulder, T., Zaragosi, S., Jouanneau, J.-M., Bellaiche, G., Guérinaud, S., Querneau, J., in press, Deposits related to the break of the Malpasset Dam in 1959: an analogy for hyperpycnal deposits from jo“kulhlaups: Marine Geology.

Parker, G., 1982. Conditions for the ignition of catastrophically erosive turbidity currents. Marine Geology, 46: 307-327.

Parsons, J.D., Bush, J.W.M., Syvitski, J.P.M., 2001. Hyperpycnal plume formation from riverine outflows with small sediment concentrations. Sedimentology, 48(2): 465-478.

Pickering, K.T., Hiscott, R.N., Hein, F.J., 1989. Deep marine environments: clastic sedimentation and tectonics. Unwin Hyman, London, 416 pp.

Piper, D.J.W., Cochonat, P., Ollier, G., LeDrezen, E., Morrison, M., Baltzer, A., 1992. Evolution progressive d'un glissement rotationnel en un courant de turbidité: cas du séisme de 1929 des Grands Bancs (Terre-Neuve). Comptes Rendus de l'Académie des Sciences de Paris, 314(Série II): 1057-1064.

Piper, D.J.W., Deptuck, M., 1997. Fine-grained turbidites of the Amazon fan: facies characterization and interpretation. In: R.D. Flood, D.J.W. Piper, A. Klaus and P. L.C. (Editors), Proceedings of the Ocean Drilling Program, Scientific Results, pp. 79-108.

Piper, D.J.W., Normark, W.R., 2001. Sandy fans - from Amazon to Hueneme and beyond. American Association of Petroleum Geologist Bulletin, 85(8): 1407-1438. 
Piper, D.J.W., Normark, W.R., 2009. Processes that initiate turbidity currents and their influence on turbidites: A marine geology perspective. Journal of Sedimentary Research, 79: 347-362.

Piper, D.J.W., Savoye, B., 1993. Processes of late Quaternary turbidity current flow and deposition on the Var deep-sea fan, north-west Mediterranean Sea. Sedimentology, 40(3): 557-582.

Prior, D.B., Bornhold, B.D., 1989, Submarine sedimentation on a developing Holocene fan delta: Sedimentology, v. 36, p. 1053-1076.

Pye, K., 1994. Properties of sediment particles. In: K. Pye (Editor), Sediment Transport and Depositional Processes. Blackwell : Oxford pp. 1-24.

Ravenne, C., Beghin, P., 1983. Apport des expériences en canal à l'interprétation sédimentologique des dépôts de cônes détritiques sous-marins. Revue de l'I.F.P., 38: 279-297.

Robbins, J.A., Edgington, D.N., 1975. Determination of recent sedimentation rates in Lake Michigan using Pb-210 and Cs-137. Geochimica et Cosmochimica Acta, 39(3): 285-304.

Sage, L., 1976. La sédimentation à l'embouchure d'un fleuve côtier méditerranéen. Thèse de doctorat / université de Nice: 243 p.

Sammari, C., Millot, C., Prieur, L., 1995. Aspects of the seasonal and mesoscale variabilities of the Northern Current in the western Mediterranean Sea inferred from the PROLIG-2 and PROS6 experiments. Deep-sea research. Part 1. Oceanographic Research papers, 42(6): 893-917.

Savoye, B., Piper, D.J.W., 1993. Quaternary sea-level change and sedimentation on the continental shelf and slope of Antibes, French Riviera. Geo-Marine Letters, 13: 2-8.

Savoye, B., Piper, D.J.W., Droz, L., 1993. Plio-pleistocene evolution of the Var deep-sea fan off the French Riviera. Marine and Petroleum Geology, 10(6): 550-571.

Schmidt, S., Howa, H., Mouret, A., Lombart, F., Anschutz, P., Labeyrie, L., in press. Particle fluxes and recent sediment accumulation on the Aquitanian margin of Bay of Biscay. Continental Shelf Research, In Press, Corrected Proof.

Schmidt, S., Jouanneau, J-M., Weber, O., Lecroart, P., Radakovitch, O., Gilbert, F., Jezequel, D., 2007. Sedimentary processes in the Thau Lagoon (France): From seasonal to century time scales. Estuarine, Coastal and Shelf Science, 72(3): 534-542.

Stow, D.A.V., Bowen, A.J., 1980. A physical model for the transport and sorting of fine-grained sediment by turbidity currents. Sedimentology(27): 31-46.

Taupier-Letage, I., Millot, C., 1985. General hydrodynamical features in the Ligurian sea inferred from the DYOME experiment. Oceanologica Acta, 9(2): 119-131.

Unterseh, S., 1999. Cartographie et caractérisation du fond marin par sondeur multifaisceaux. Doctorat Thesis, I.N.P.L., 234 pp.

Wheatcroft, R.A., Drake, D.E., 2003. Post-depositional alteration and preservation of sedimentary event layers on continental margins, I. The role of episodic sedimentation. Marine Geology, 199(1-2): 123-137. 


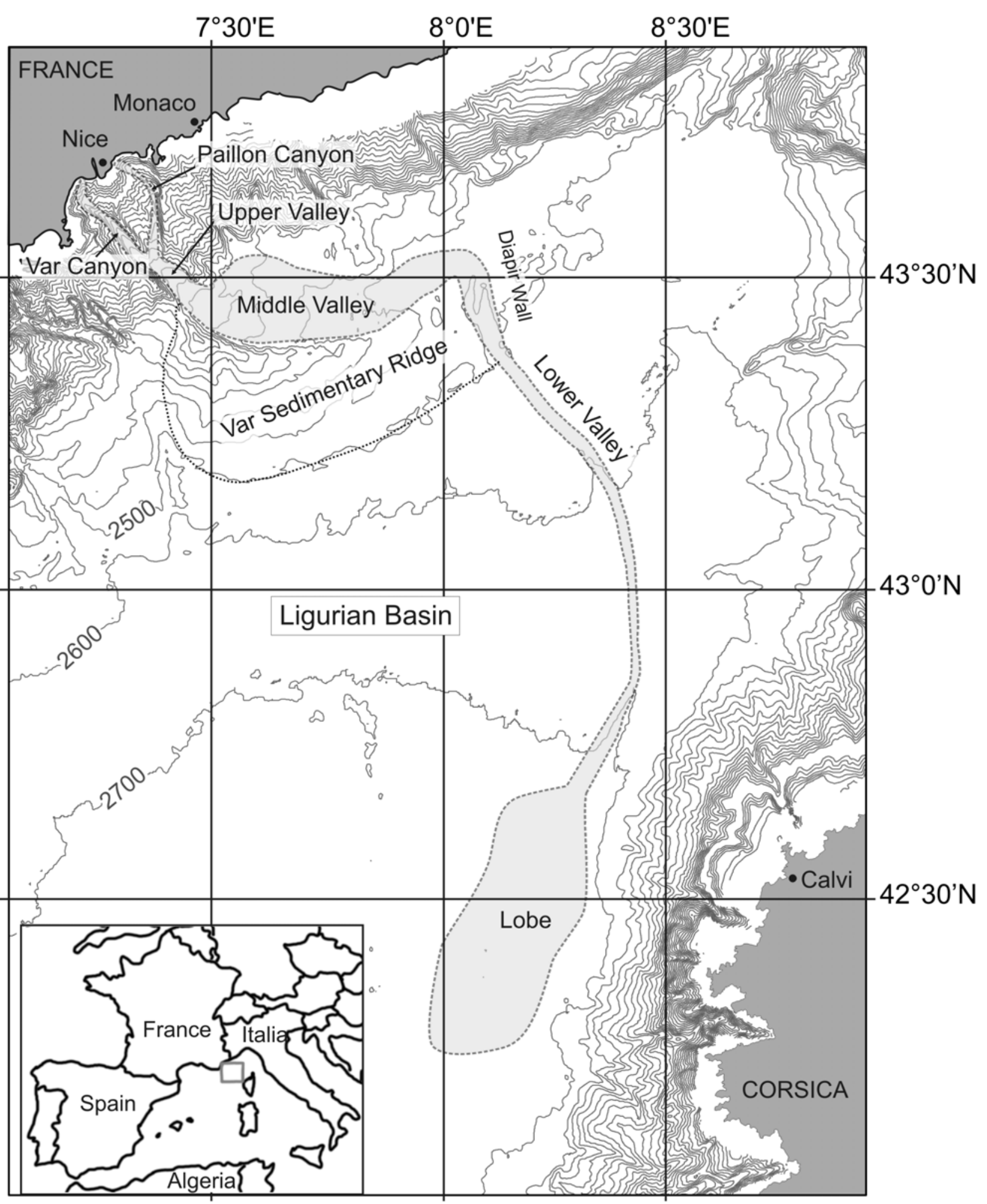

849 Figure 1: Location map of the Western Mediterranean Sea showing the Var Deep-Sea Turbidite

850 System in the Ligurian Basin. Bathymetry is from IFREMER Database. 


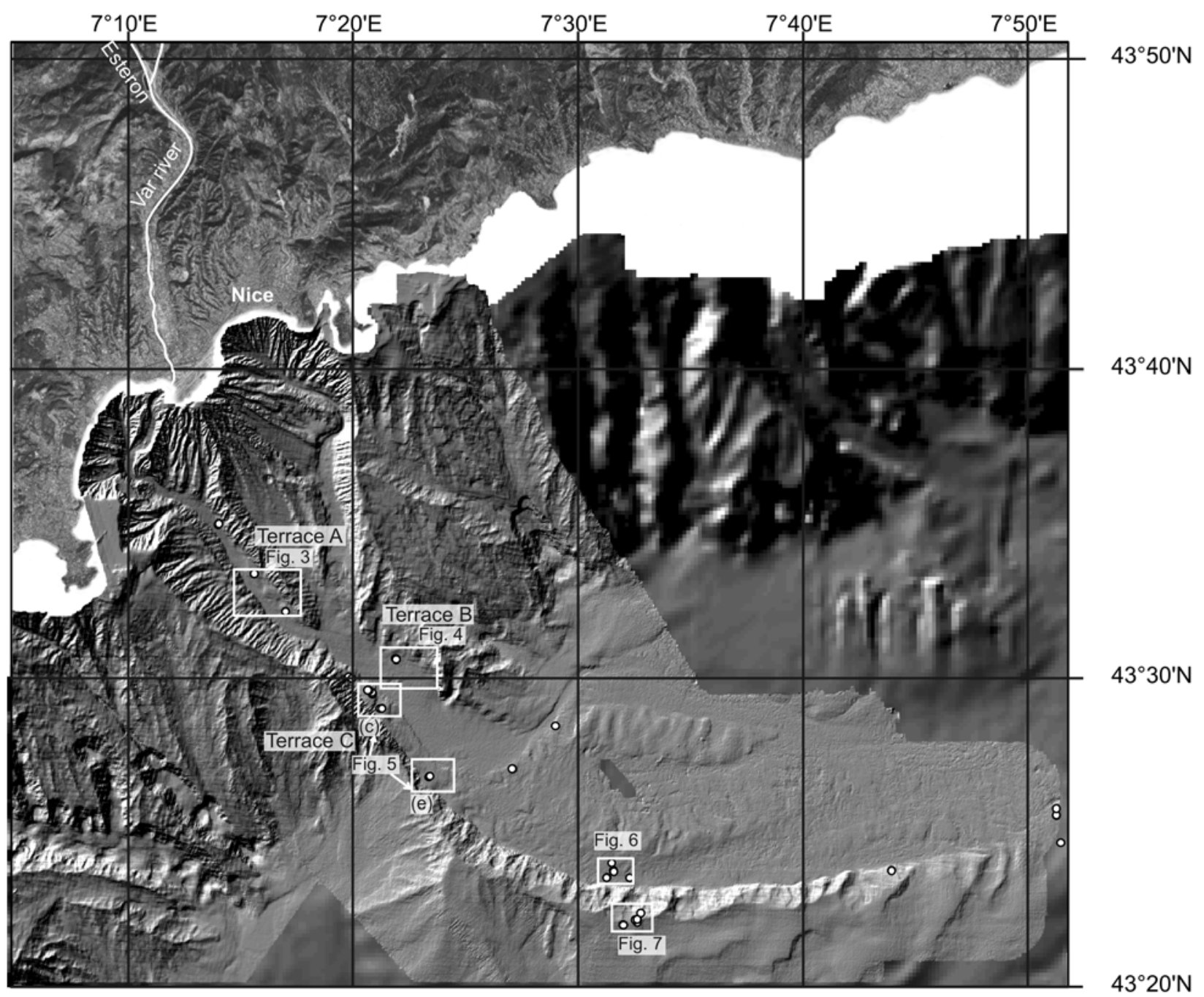

852

853 Figure 2: Shaded topographic map of the study area. Rectangles indicate location of blow-up of

854 side-scan sonar images. White dots indicate location of sediment cores.

855 

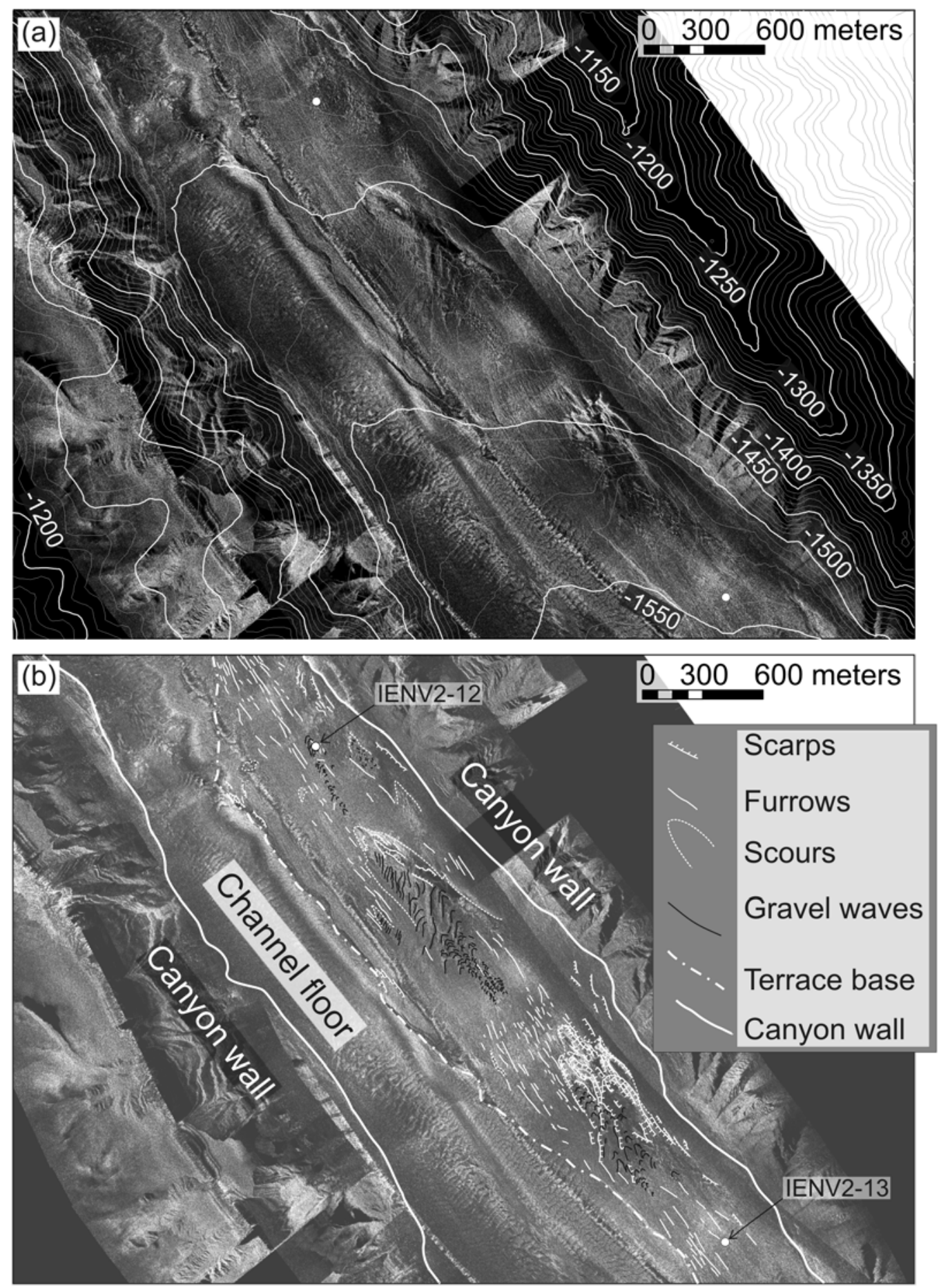

857 Figure 3: (a) SAR imagery and bathymetric contours showing Var Canyon terrace A ( 1400 1640

858 m WD). (b) interpretation of the morphology and bedforms. See Fig. 2 for location. White dots

859 indicate location of sediment cores. 

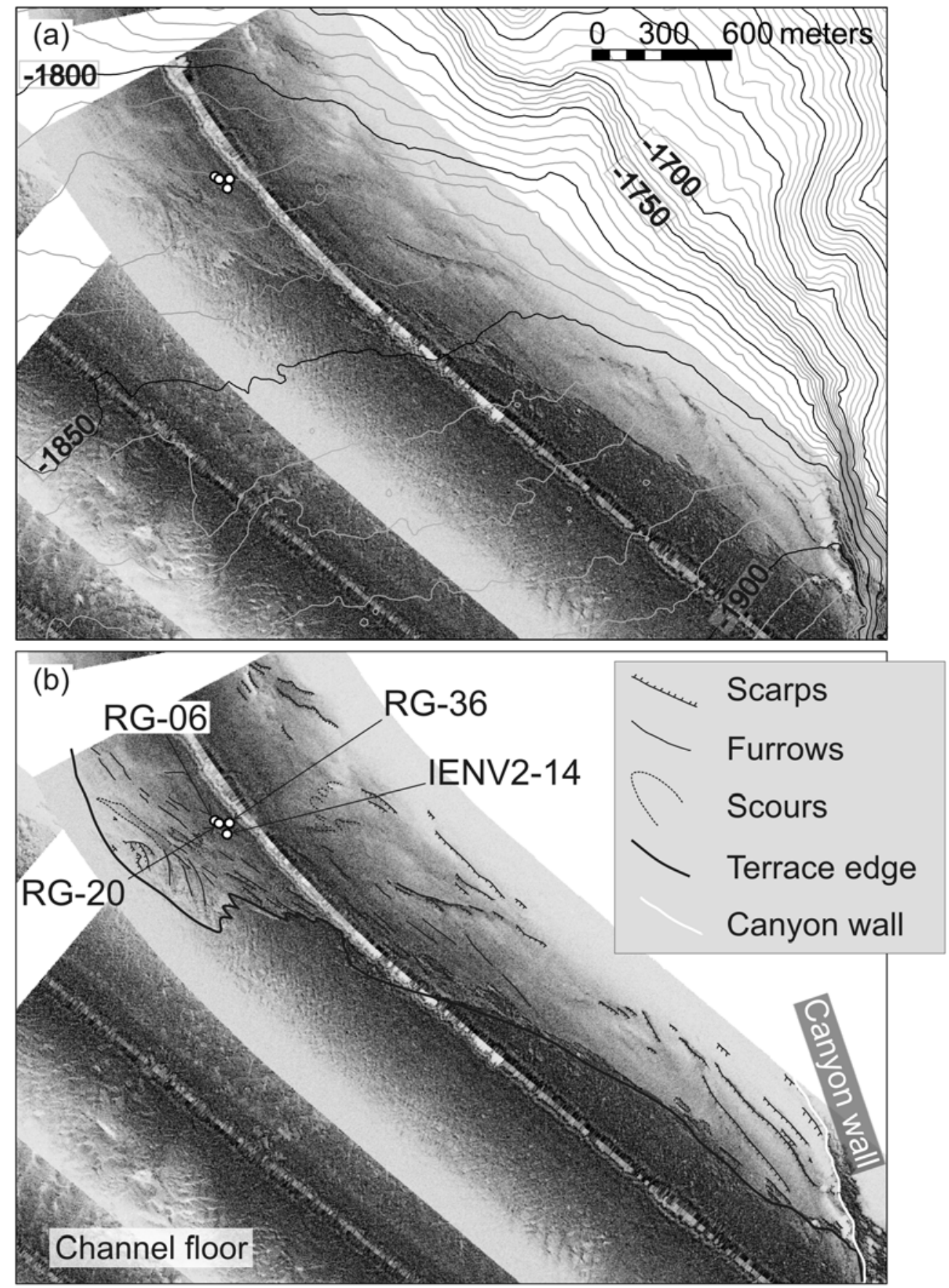

862 Figure 4: (a) SAR imagery and bathymetric contours showing terrace B (left hand side terrace). (b)

863 interpretation of the morphology and bedforms. See Fig. 2 for location. White dots indicate location 864 of sediment cores. 

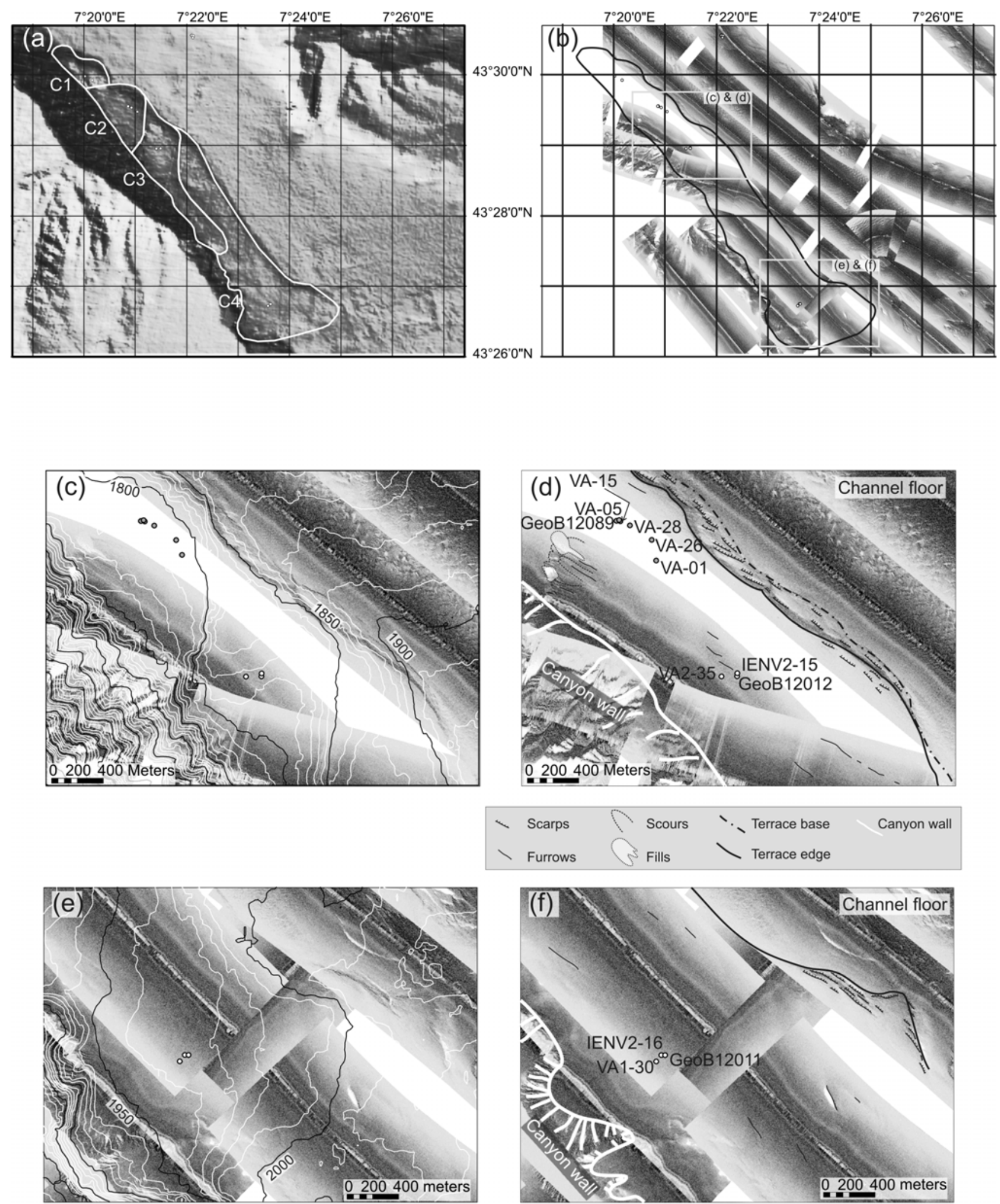

867 Figure 5: (a) Shaded bathymetry of the area with sub-terraces C1, C2, C3 and C4 (right hand side

868 terrace the Upper Valley, (b) SAR imagery and (c) blow-up of side-scan sonar image of sub-terraces

869 C2 and C3, (d) interpretation of the morphology and bedforms on sub-terraces C2 and C3 (e) blow-

870 up of side-scan sonar image of sub-terrace C4 (f) interpretation of the morphology and bedforms on

871 the sub-terrace C4. See Fig. 2 for location. White dots indicate location of sediment cores. 

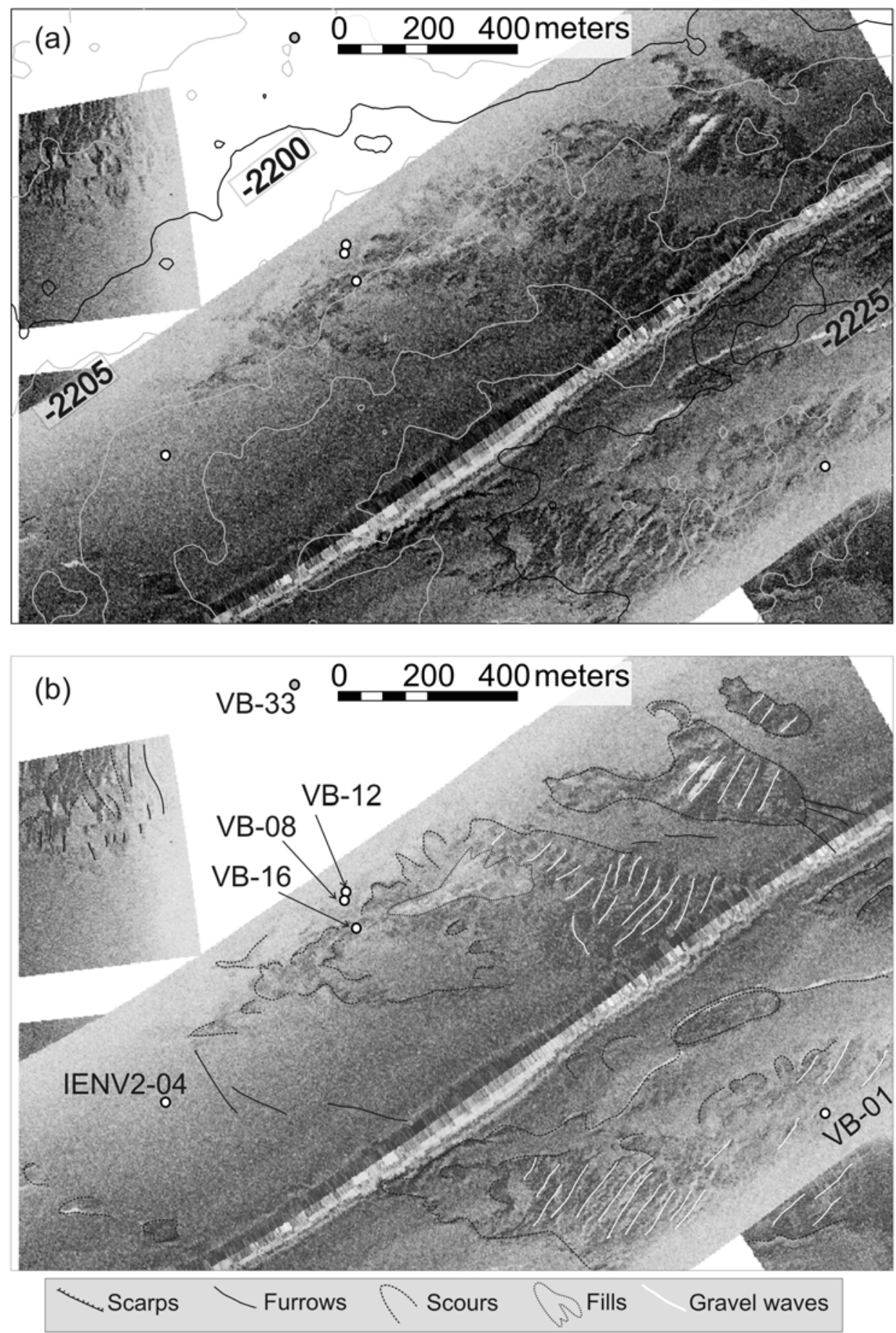

874 Figure 6: (a) SAR imagery and bathymetric contours showing a part of the channel floor in the

875 Middle Valley, (b) interpretation of the morphology and bedforms. See Fig. 2 for location. White

876 dots indicate location of sediment cores. 

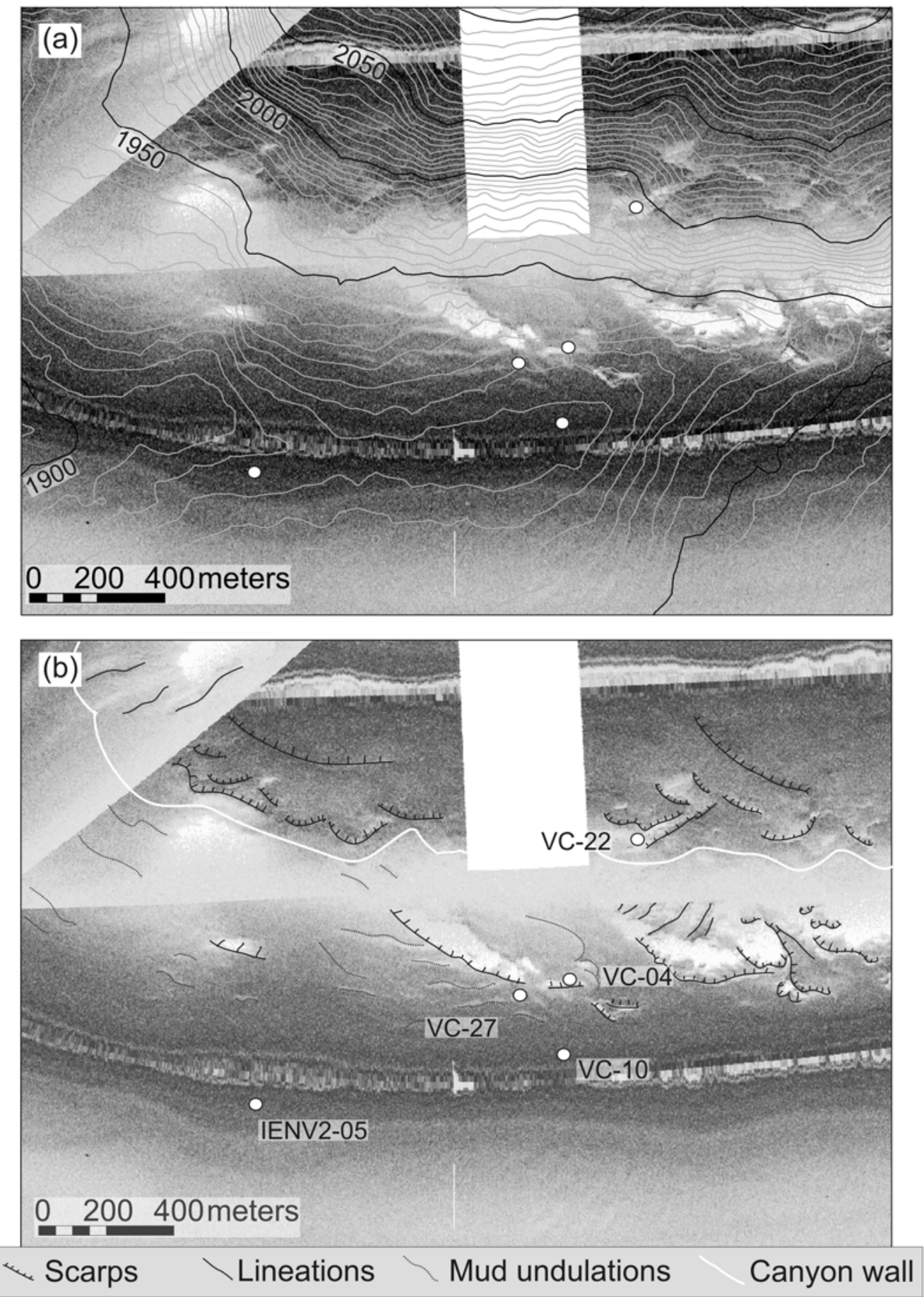

879 Figure 7: (a) SAR imagery and bathymetric contours on the crest of the Var Sedimentary Ridge, in 880 the Middle Valley; (b) interpretation of the morphology and bedforms. See Fig. 2 for location. White 881 dots indicate location of sediment cores. 
Mas et al., Marine Geology, corrected version

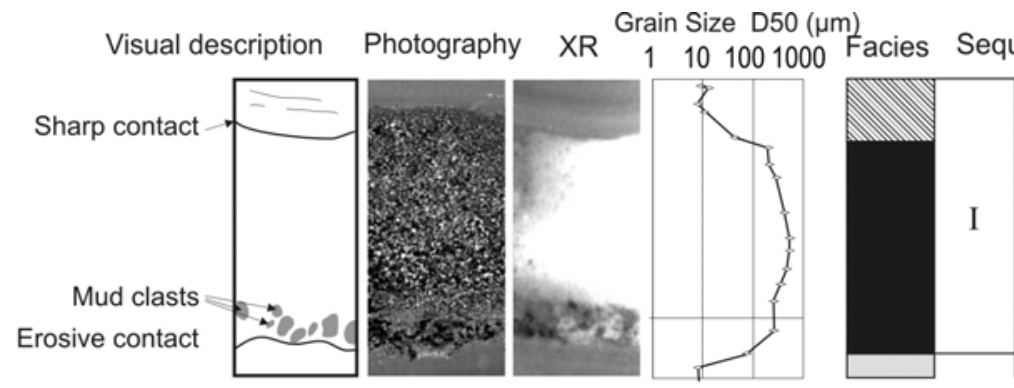

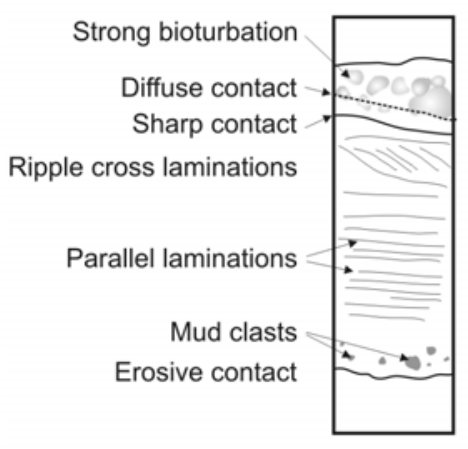
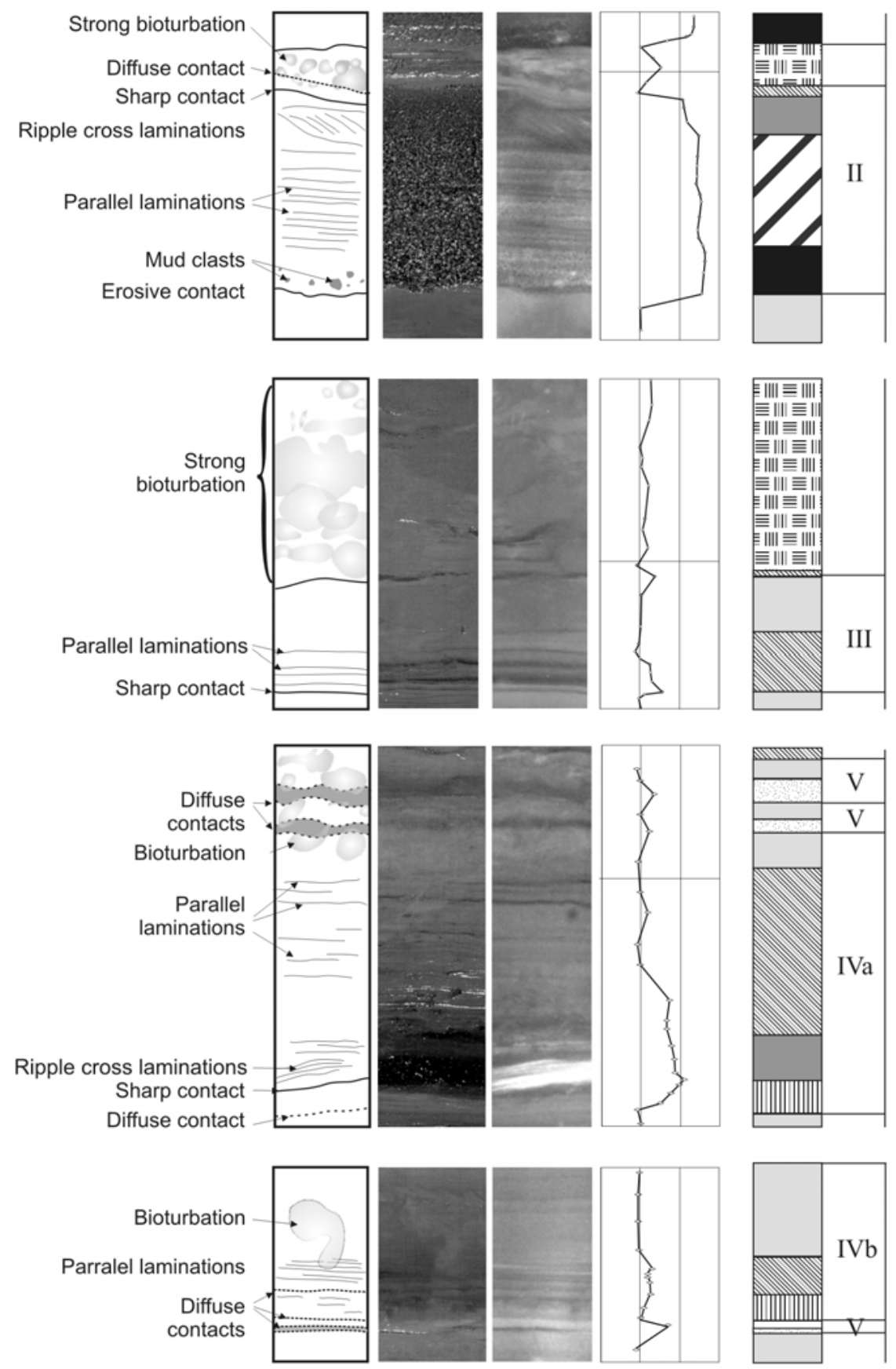

Ripple cross laminations

Diffuse contacts

Pebbles

Erosional contact

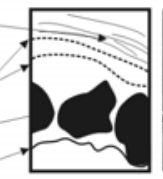

(a)

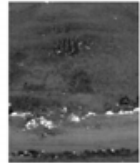

(b)

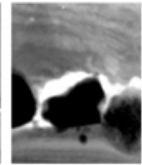

(c)

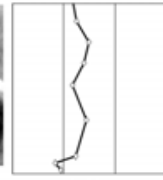

(d)

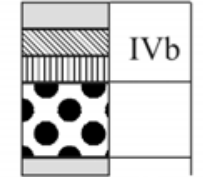

(e) (f)

\section{Facies}

1 : Pebble layer

2: Massive or poorly graded sand

3: Laminated graded sand

4 : Fine sand with possible sedimentary structures

$\mathbb{1}$ 5a: Graded silt

$\square$ b : silty clay

\section{$\square$ 6: Hemipelagite}

ㄸ山ा سل 7 : inversely graded sediment 8 : blurred silty layer

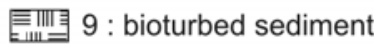

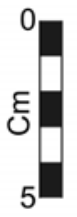


Mas et al., Marine Geology, corrected version

884 Figure 8: Sedimentary facies and sequences found in the Var system, represented by (a) visual

885 description and sedimentary structures informations, (b) photograph, (c), X-Ray image, (d) main 886 grain size, (e) facies and (f) sequences.

887 

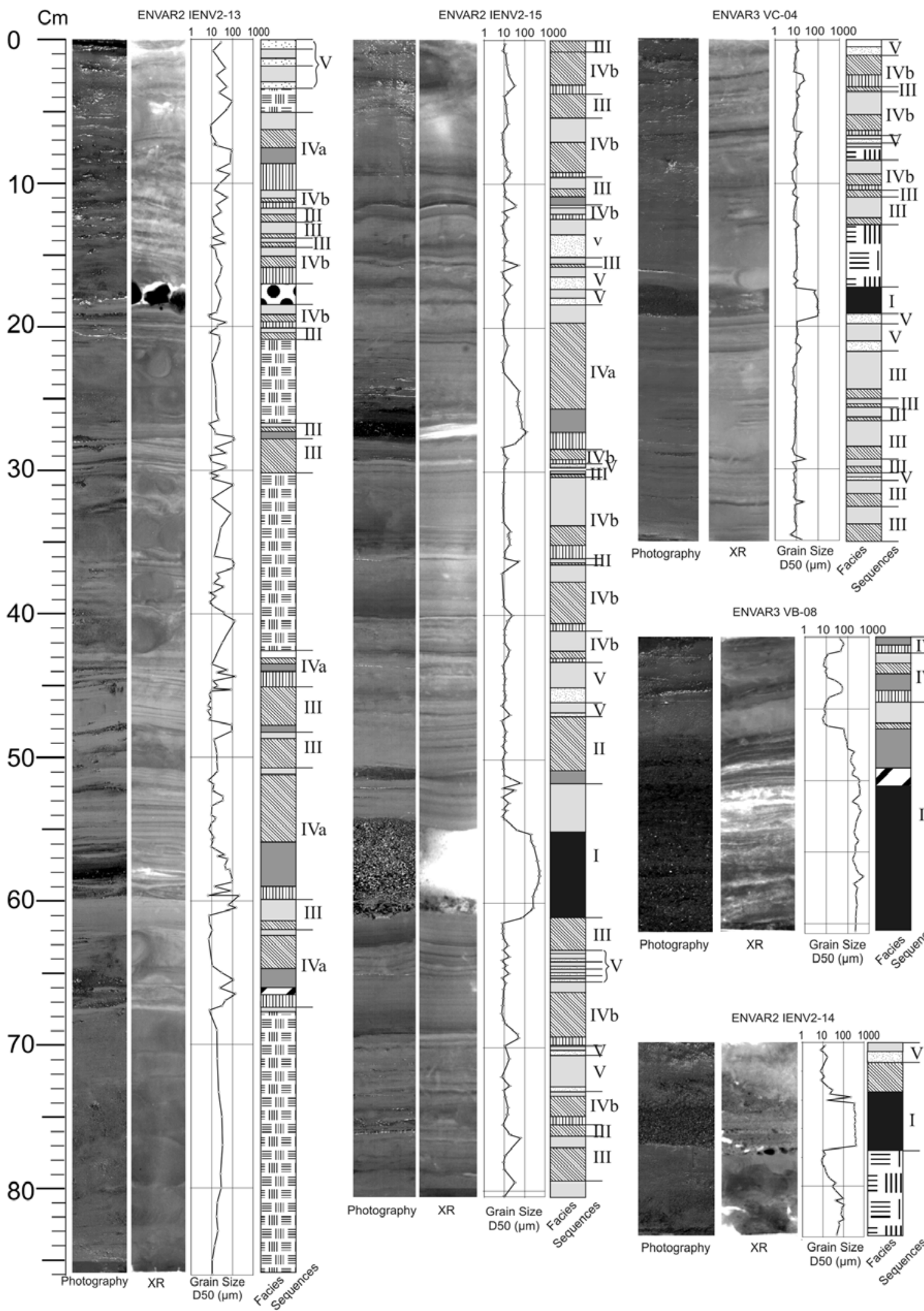

ENVAR3 VB-08
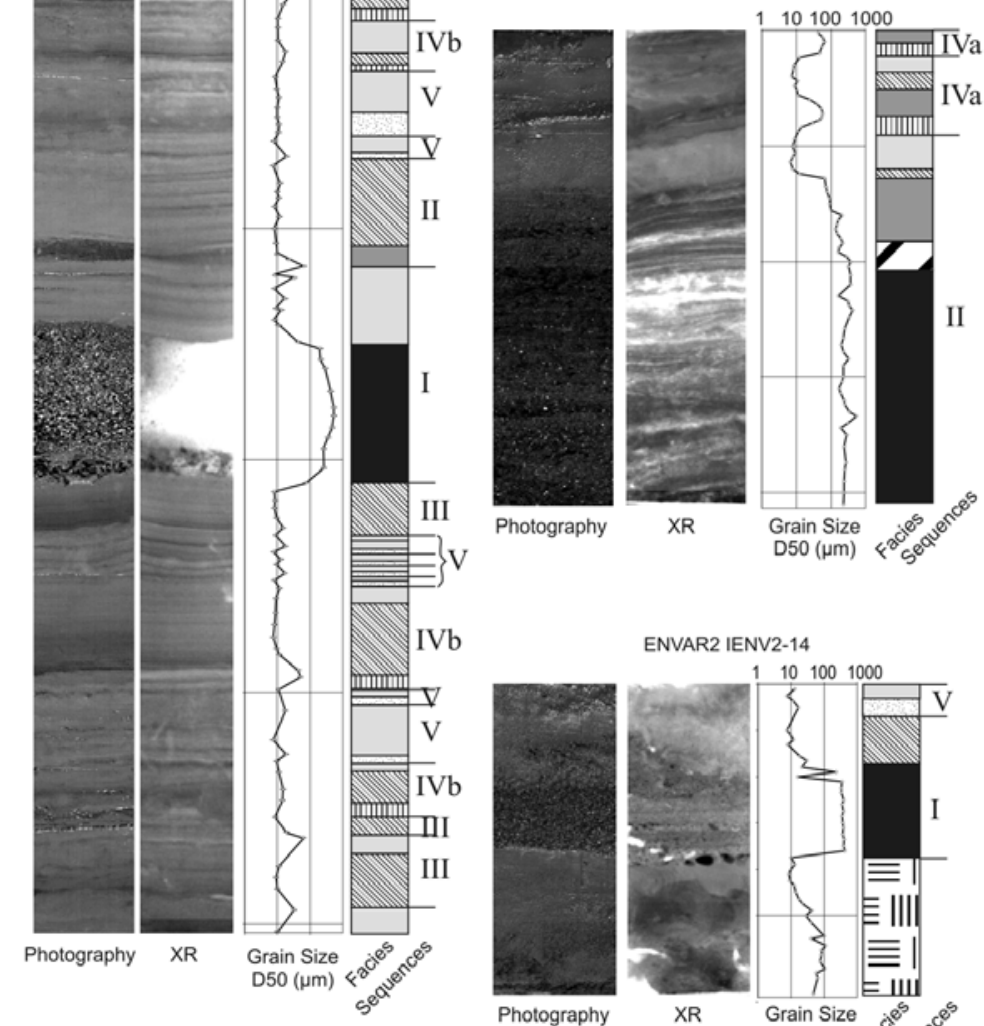

\section{4}

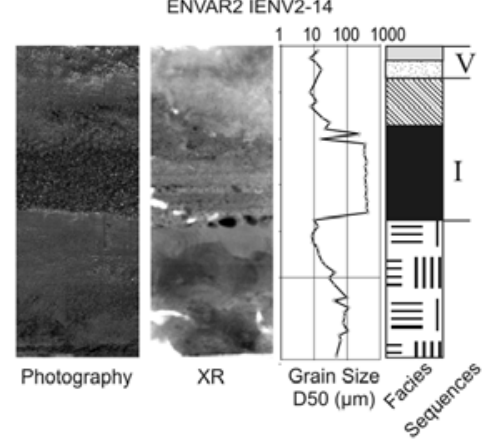

Facies
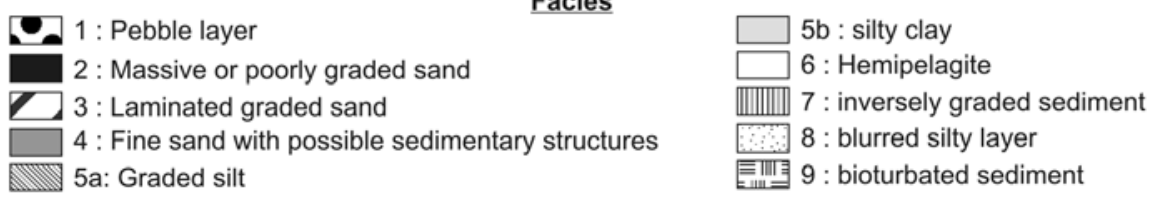
889 Figure 9: Photographs, X-ray images (XR) and median of the grain-size curve (D50) showing the

890 vertical distribution of facies and sequences on cores from terrace A (IENV2-13), terrace B (IENV2-

891 14), sub-terrace C3 (IENV2-15), from the middle valley channel floor (VB-08) and from the crest of 892 the Var Sedimentary Ridge (VC-04).

893

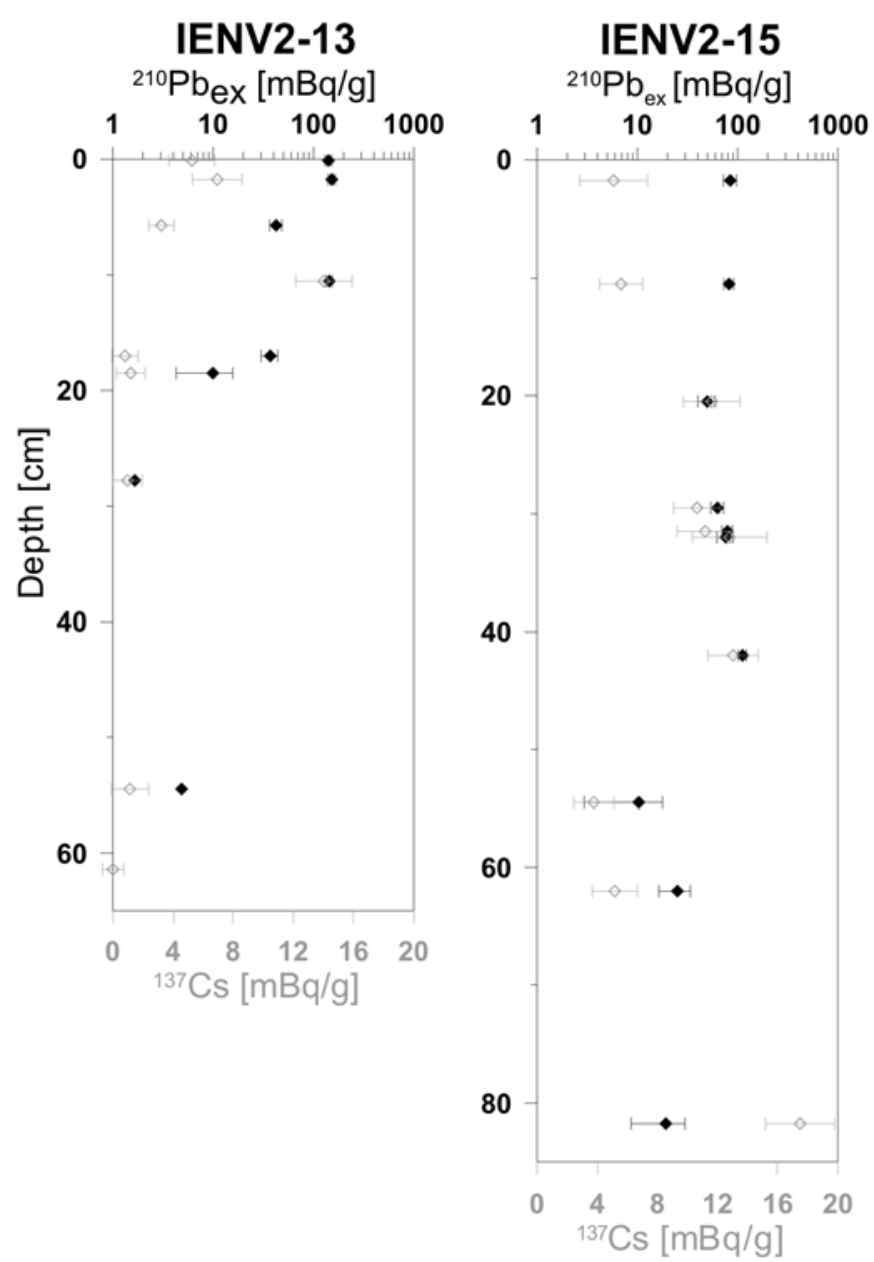

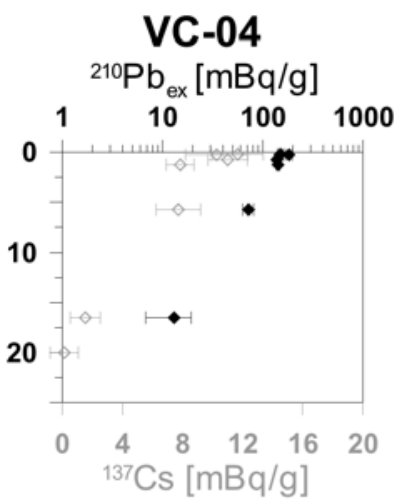

VB-08

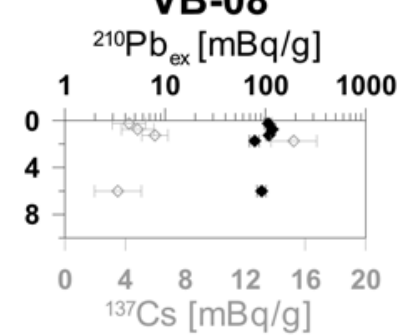

IENV2-14

894

895 Figure 10: Values of ${ }^{210} \mathrm{~Pb}_{\mathrm{ex}}$ and ${ }^{137} \mathrm{Cs}$ versus depth on cores from terrace A (IENV2-13), terrace B 896 (IENV2-14), sub-terrace C3 (IENV2-15), from the middle valley channel floor (VB-08) and from the

897 crest of the Var Sedimentary Ridge (VC-04). 


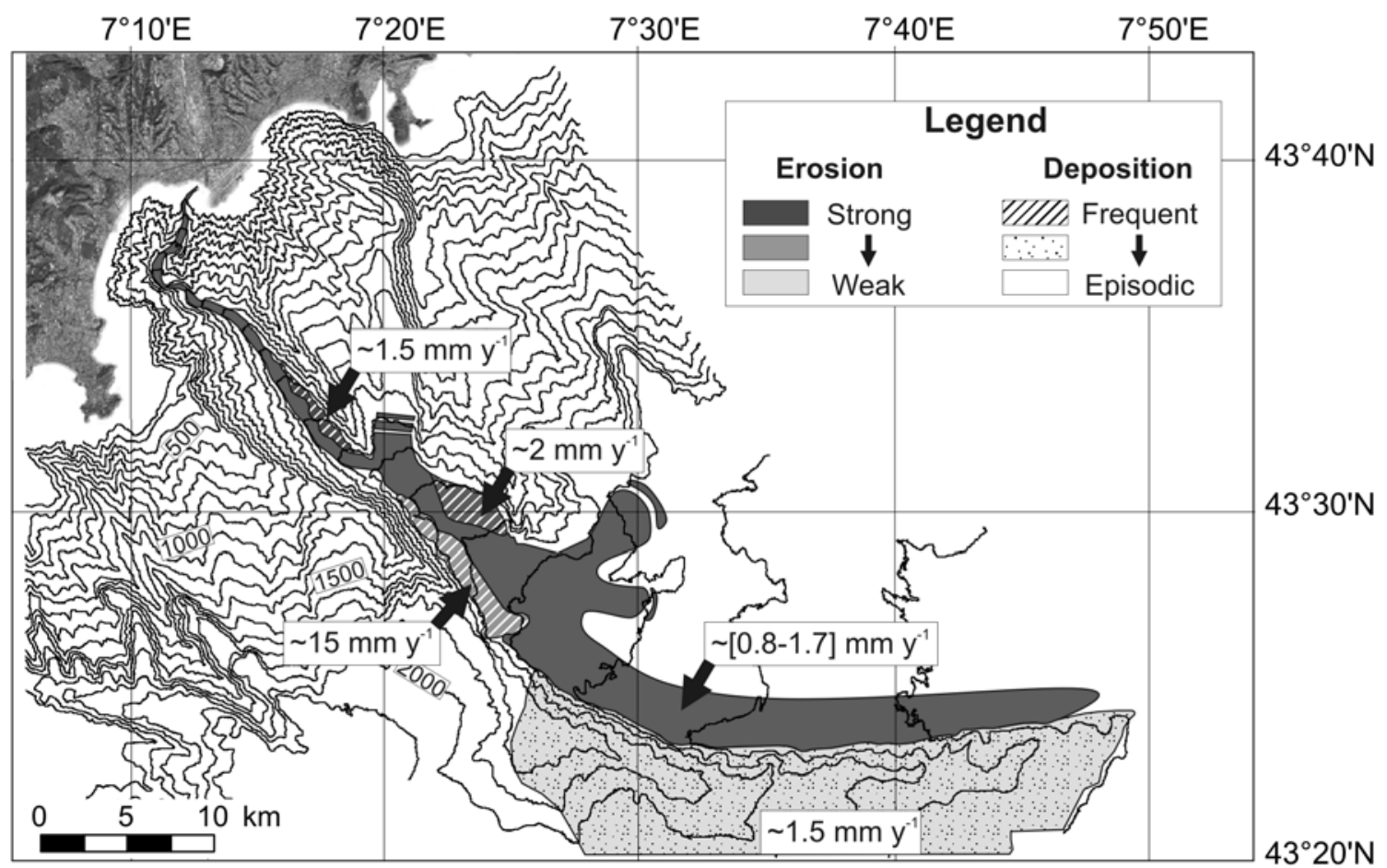

900 Figure 11: Schematic map of depositional and erosional processes for each studied area, i.e. the

901 terraces A, B and C, the channel floor and the levee. Colour indicates the relative abundance of

902 erosional features observed on cores and SAR imagery, and patterns indicate the relative level of

903 deposition during the last century, according to the mean sedimentation rate and the number of

904 sequences deposited and preserved. The sedimentation rate given for each area is calculated with

905 three cores on the levee and in terrace A, two cores in the channel, in terrace B and sub-terrace C3,

906 and one core in sub-terraces C1, C3 and C4. 


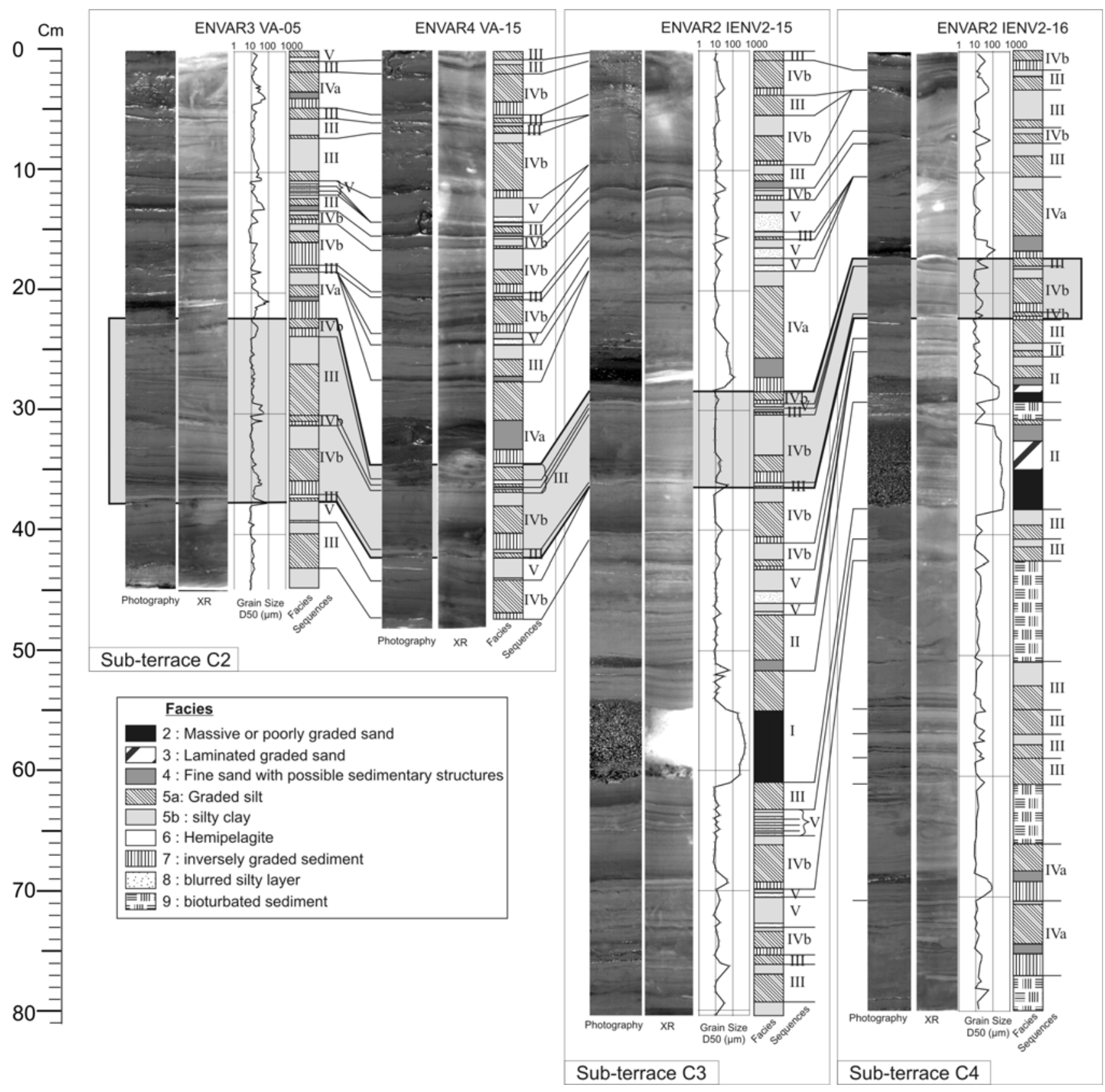

909 Figure 12: Photograph, X-ray images (XR), and median of the grain-size curve (D50) showing the

910 vertical distribution of facies and sequences on cores from sub-terraces C2 (VA-05 and VA-15), C3

911 (IENV2-15) and C4 (IENV2-16) (see Fig. 5 for cores location). Correlations between cores are based

912 on visual description, grain size measurements and radioisotopes $\left({ }^{210} \mathrm{~Pb}\right.$ ex and $\left.{ }^{137} \mathrm{Cs}\right)$.

\section{Table:}




\begin{tabular}{|c|c|c|c|c|c|c|c|c|c|}
\hline & & $A$ & & & & & & & \\
\hline $\begin{array}{l}\text { Accumulat } \\
\text { Rate (mm }\end{array}$ & & $2.5-4$ & $0.4-1.5$ & $>9.2$ & $>9.6$ & $>16$ & 14 & $0.9->1.8$ & $1.3-2$ \\
\hline $\begin{array}{l}\text { Mean numb } \\
\text { sequence }\end{array}$ & s of & 7 & 3 & $>12$ & $>23$ & $>33$ & 20 & $>4$ & 6 \\
\hline Mean & 1 & $0(0)$ & $1(25)$ & $0(0)$ & $0(0)$ & $1(7)$ & $0(0)$ & $0(0)$ & $0(0)$ \\
\hline number of & II & $0(0)$ & $0(0)$ & $0(0)$ & $0(0)$ & $1(7)$ & $2(23)$ & $1(65)$ & $0(0)$ \\
\hline sequences & III & $3(50)$ & $1(25)$ & $3(19)$ & $10(32)$ & $9(19)$ & $13(46)$ & $1(13)$ & $3(49)$ \\
\hline by type (and & IVa & $1(23)$ & $0(0)$ & $1(40)$ & $2(16)$ & $1(13)$ & $2(20)$ & $2(22)$ & $0(0)$ \\
\hline percentage & $\mathrm{IVb}$ & $1(15)$ & $0(0)$ & $6(28)$ & $7(43)$ & $9(35)$ & $3(11)$ & $0(0)$ & 1 (23) \\
\hline & $\mathrm{V}$ & $2(11)$ & $1(50)$ & $2(13)$ & $4(9)$ & $12(19)$ & $0(0)$ & $0(0)$ & $2(28)$ \\
\hline
\end{tabular}

918 Table 1: Statistical analyses on the distribution of the sequences during the last century. For each

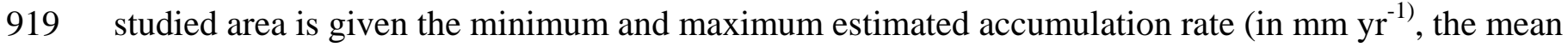

920 number of sequences deposited through the last century, calculated with three cores on the levee and

921 in terrace A, two cores in the channel, in terrace B and sub-terrace C3, and one core in sub-terraces

922 C1, C3 and C4. The mean number of sequence is detailed by type and the relative percentage of

923 sediment deposited is given in parentheses. Note that where ${ }^{137} \mathrm{Cs}$ is still detected at the base of core,

924 the estimated accumulation rate is a minimal value (noted by ">") given for the last 50 years. Note

925 also that for cores where ${ }^{137} \mathrm{Cs}$ is still detected at the base of the core, the average number of

926 sequences is deposited in less than 50 years. 